\title{
Equilibria and Speciation of Chloramines, Bromamines, and Bromochloramines in Water
}

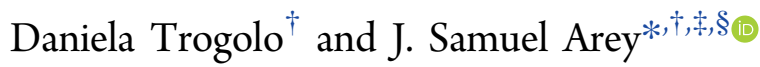 \\ $\dagger$ École Polytechnique Fédérale de Lausanne (EPFL), Lausanne, Switzerland \\ ${ }^{\ddagger}$ Eawag, Swiss Federal Institute of Aquatic Science and Technology, Dübendorf, Switzerland
}

\section{Supporting Information}

ABSTRACT: The stabilities and speciation of the halamines in water are difficult to characterize experimentally. We provide theoretical estimates of aqueous standard free energies of formation for inorganic chloramines, bromamines, and bromochloramines, based on high-accuracy theoretical standard free energies of formation in gas phase combined with quantum chemical estimates of Henry's law constant. Based on comparisons between several theoretical and experimental datasets, we assign an error of 1.1-1.2 log unit for equilibrium constants of several reactions leading to halamines in water. The reactions of ammonia with $\mathrm{HOCl}$ or $\mathrm{HOBr}$ that lead to dichloramine, trichloramine, and tribromamine are found to be

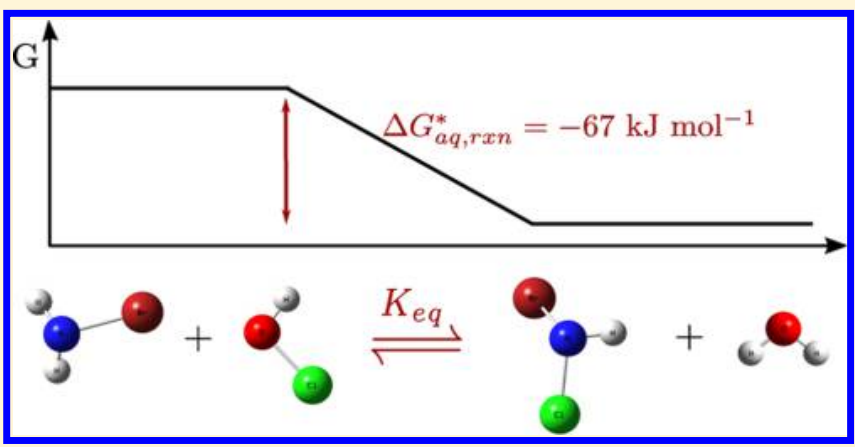
thermodynamically more favorable than was previously believed. The newly reported equilibrium data also allow us to propose rate constant values for some hydrolysis and disproportionation reactions of dichloramine, monobromamine, and bromochloramine. Finally, theoretical results indicate aqueous acid dissociation constant $\left(\mathrm{pK}_{\mathrm{a}}\right)$ values of $1.5 \pm 1$ for $\mathrm{NH}_{3} \mathrm{Cl}^{+}$, $0.8 \pm 1$ for $\mathrm{NH}_{3} \mathrm{Br}^{+}, 11.8 \pm 1$ for $\mathrm{NHCl}_{2}$, and $12.5 \pm 1$ for $\mathrm{NHBrCl}$. The present report provides a comprehensive data set describing the free energies of the neutral inorganic halamines, the anionic conjugate base species, and the cationic conjugate acid species, with approximately uniform uncertainty bounds assigned throughout.

\section{INTRODUCTION}

Aqueous chloramines, bromamines, and bromochloramines, collectively termed halamines in the present work, typically arise from the $\mathrm{N}$-substitution reactions of hypohalous acids with ammonia: ${ }^{1-16}$

$$
\begin{aligned}
& \mathrm{NH}_{3, \mathrm{aq}}+\mathrm{HOX}_{\mathrm{aq}} \stackrel{\mathrm{K}_{\mathrm{aq}}}{\rightleftharpoons} \mathrm{NH}_{2} \mathrm{X}_{\mathrm{aq}}+\mathrm{H}_{2} \mathrm{O}_{\mathrm{l}} \\
& \mathrm{NH}_{2} X_{\mathrm{aq}}+\mathrm{HOX}_{\mathrm{aq}} \stackrel{\mathrm{Kaq}_{\mathrm{aq}}}{\rightleftharpoons} \mathrm{NHX}_{2, \mathrm{aq}}+\mathrm{H}_{2} \mathrm{O}_{\mathrm{l}} \\
& \mathrm{NHX}_{2, \mathrm{aq}}+\mathrm{HOX}_{\mathrm{aq}} \stackrel{K_{\mathrm{aq}}}{\rightleftharpoons} \mathrm{N} X_{3, \mathrm{aq}}+\mathrm{H}_{2} \mathrm{O}_{1}
\end{aligned}
$$

where $X$ is either $\mathrm{Cl}$ or $\mathrm{Br}$. Dichloramine, ${ }^{5,6,17,18}$ dibromamine, ${ }^{8,14,19}$ and bromochloramine ${ }^{20}$ can also form by disproportionation reactions. Chloramines are applied widely as disinfectants in water treatment facilities, and their decomposition is directly implicated in the production of potentially toxic disinfection byproducts (DBPs). ${ }^{21-44}$ During chloramination of natural waters, chloramines can provide the nitrogen source for the formation of several families of nitrogenous disinfection byproducts, including halonitriles, ${ }^{32,37}$ halonitroalkanes, ${ }^{32,37}$ and nitrosamines. ${ }^{32,33,38-45}$ Chloramines can also participate in substitution and redox reactions with organic micropollutants. ${ }^{31,40,41,45-47}$
The presence of naturally occurring bromide in fresh waters can potentially lead to the production of hypobromous acid, bromamines, and bromochloramines, during chlorination, chloramination, or ozonation of natural waters. $^{8,10,12,15,19,20,44,48-53}$ During oxidative treatment of natural water, bromide can react with hypochlorous acid to produce $\mathrm{HOBr},{ }^{54,55}$ which can subsequently brominate ammonia and substituted amines, thereby producing bromamines (eqs 1-3). These species can then further react rapidly to form dibromamine, tribromamine, and bromochloramines (eqs 1-3). ${ }^{19,20,51,52,56,57}$ Bromamines and bromochloramines can lead to the production of potentially toxic DBPs in water as well. ${ }^{58-61}$ For example, $\mathrm{NHBr}_{2}$ and $\mathrm{NHBrCl}$ are thought to be involved in the production of $\mathrm{NDMA}^{59,60}$ and of $\mathrm{CNBr}^{58,61}$ during water disinfection.

Chloramines and bromamines also arise in activated neutrophil and eosinophil cells during inflammatory disease affecting mammals, due to the reactions of $\mathrm{HOCl}$ or $\mathrm{HOBr}$ with nitrogen-contain biological molecules such as proteins and amino acids. ${ }^{62,63}$ Thus, formed bromamines and chloramines can undergo oxidation reactions with $\mathrm{O}_{2}{ }^{-63}$ or metal ions, ${ }^{64,65}$

Received: July 8, 2016

Revised: November 6, 2016

Accepted: November 17, 2016

Published: December 16, 2016 
generating nitrogen- and carbon-centered radicals. The spontaneous decomposition of such radical intermediates can damage the cell, inducing protein fragmentation, protein modification, and tissue damage. ${ }^{64,65}$

Despite that the halamines have been studied for several decades, chemical equilibrium constants remain highly uncertain for relevant formation, disproportionation, and protonation/deprotonation reactions of many of these species. The rate constants and the equilibrium constants of the reactions involving chloramines are difficult to measure because several short-lived species can arise simultaneously, and in many cases these values must be constrained with kinetic models. ${ }^{1,3,9,13,18,20,66,67}$ The equilibria and the kinetics describing the production of bromamines and mixed halamines are also incomplete. ${ }^{11,19,49,51,68,69}$ Further complicating matters, the acid dissociation constant $\left(\mathrm{p} K_{a}\right)$ values remain unknown for most of the neutral chloramines, bromamines, and bromochloramines and also for their cationic conjugate acids. 4,70

Quantum chemical models provide an alternative approach for the determination of the aqueous equilibria of halamines. For example, chlorination reactions of amino functional groups were studied recently by computational chemical approaches. ${ }^{71-74}$ Rayson et al. ${ }^{72}$ and Andrés et al. ${ }^{71}$ investigated the oxidation of ammonia with $\mathrm{HOCl}$ by employing density functional methods. In other work, the G3B $3^{75}$ composite method was used to describe $N$-chlorination reactions of organic amines by $\mathrm{HOCl}^{73}$ Theoretical methods were also used by Rayne and Forest to estimate aqueous free energies of reactions leading to chloramines (eqs $1-3) .{ }^{74}$ However, these approaches do not achieve sub-kcal mol ${ }^{-1}$ accuracy in the free energies of the aqueous reactions leading to chloramines. For example, the gas phase theoretical enthalpies of reaction of Rayne and Forest exhibit discrepancies with respect to more accurate benchmark data published recently. ${ }^{76,77}$ Standard heats of formation $\left(\Delta H_{f}^{o}\right)$ and standard free energies of formation $\left(\Delta G_{f}^{o}\right)$ in gas phase were determined recently using highaccuracy theoretical methods for chloramines, bromamines, and bromochloramines, and these data were assigned uncertainties of $1-3 \mathrm{~kJ} \mathrm{~mol}^{-1} \cdot{ }^{76,77}$ However, the influence of aqueous solvent on these gas phase thermodynamic data remains to be established.

The goal of the present study is to establish reliable estimates of the standard free energies of formation and the acid dissociation constants of inorganic chloramines, bromamines, and bromochloramines in aqueous solution. We compare these theoretical results with available experimental data. Attention is paid to reporting realistic uncertainty bounds for these theoretically estimated thermodynamic properties. The results enable us to determine the aqueous equilibra for the principal pathways that generate halamines during drinking water treatment.

\section{MATERIALS AND METHODS}

Computational Estimates of Free Energies of Solvation. The free energy of aqueous solvation of a chemical species, $\Delta G_{\text {solv }}^{*}$, describes its equilibrium distribution between the gas and aqueous phases. According to the standard state convention used in the present study, $\Delta G_{\text {solv }}^{*}$ is defined as the energy required to transfer one mole of a chemical species from the gas phase to aqueous solution at a (hypothetically infinitely dilute) $1 \mathrm{M}$ concentration in both phases. ${ }^{78}$ The free energy of aqueous solvation is related to the experimentally measurable dimensionless Henry's law solubility constant, $K_{H}^{(-)}$:

$$
\Delta G_{\text {solv }}^{*}=R T \ln K_{H}^{(-)}
$$

More details on the conversion factors and the units of the Henry's law constant values are provided in the SI. To estimate $\Delta G_{\text {solv }}^{*}$ values of the halamines, we considered several methodological approaches, including four implicit solvent models and also a cluster-continuum approach adapted from the method of Bryantsev and co-workers. ${ }^{79}$

Implicit Solvent Models: Methods and Basis Sets. Gas phase geometries for the halamines, $\mathrm{HOCl}, \mathrm{HOBr}, \mathrm{NH}_{3}$, and $\mathrm{H}_{2} \mathrm{O}$ were computed with the $\operatorname{CCSD}(\mathrm{T})$ electronic structure method and were taken from recent high-accuracy theoretical results. ${ }^{76,77}$ The gas phase geometries of $\mathrm{Cl}_{2}, \mathrm{Br}_{2}$, and $\mathrm{NF}_{3}$ were optimized using the B2PLYPD ${ }^{80,81}$ DFT method with the augcc-pVQZ basis set, ${ }^{82-84}$ as implemented in Gaussian09. ${ }^{85}$ Harmonic frequency analyses were subsequently carried out with the same electronic structure method used to obtain the geometries.

The implicit solvent models employed were the universal solvent model based on the solute electron density ${ }^{86}$ (SMD), the polarizable conductor calculation model (CPCM) ${ }^{87,88}$ and the polarizable conductor model (PCM $)^{88-91}$ as implemented in Gaussian09, ${ }^{85}$ and the conductor-like screening model $(\mathrm{COSMO})^{92,93}$ implemented in NWChem. ${ }^{94}$ Free energies of solvation computed with these models are referred to as $\Delta G_{\text {solv,SMD }}^{*}, \Delta G_{\text {solv,CPCM}}^{*}, \Delta G_{\text {solv,PCM, }}^{*}$ and $\Delta G_{\text {solv,COSMO, respec- }}^{*}$ tively.

To obtain $\Delta G_{\text {solv,SMD }}^{*}, \Delta G_{\text {solv, CPCM }}^{*}, \Delta G_{\text {solv,PCM }}^{*}$, and $\Delta G_{\text {solv, COSMO }}^{*}$ for the species studied here, we performed B2PLYPD/aug-cc-pVQZ single point energy computations with the implicit solvent models SMD, CPCM, PCM, and COSMO, using the gas phase optimized geometries. The B2PLYPD method has been reported to give good performance for challenging multireference electronic structures such halogen oxides. ${ }^{95-98}$ To briefly test whether B2PLYPD is appropriate for the electronic structures of halamines and other halogen oxidants studied here, we evaluated gas phase total atomization energies and compared these results to recently published $^{76,77}$ benchmark values (Table S2 in the Supporting Information (SI)). Based on the good performance of the B2PLYPD method for gas phase electronic structure predictions, we carried out free energy of solvation computations with B2PLYPD. Computations with the CPCM and PCM implicit solvent models were tried with different atomic radii (UFF, UAHF, and UAKS) as implemented in Gaussian09. To consistently calculate the solvent effect with the B2PLYPD method, we included the keyword SCRF(Externaliteration) ${ }^{99,100}$ in the Gaussian09 input.

Cluster-Continuum Solvent Models: Methods and Basis Sets. The cluster-continuum approach may allow a more accurate description of aqueous solvation effects, by including an explicit electronic treatment of interactions with one or more molecules of water. ${ }^{79}$ Compared to implicit models, this approach has been found to give improved results for monatomic ions. ${ }^{79}$ The cluster-continuum approach has also been applied for neutral and charged organic molecules. ${ }^{95}$ We obtained cluster-continuum results in combination with both the SMD and COSMO implicit solvent models. To apply this method, we employ a microsolvated cluster that contains the molecule of interest and one explicitly modeled molecule of water, together embedded in a conventional implicit solvent model. For the neutral halamine species studied here, a stable binary complex can be made between the halamine molecule 
Table 1. Gibbs Free Energies of Solvation for $\mathrm{Cl}_{2}, \mathrm{Br}_{2}, \mathrm{NF}_{3}, \mathrm{NH}_{3}, \mathrm{H}_{2} \mathrm{O}, \mathrm{HOCl}$, Inorganic Chloramines, and Methylated Amines: Experimental Values and Theoretical Estimates. Values are in $\mathrm{kJ} \mathrm{mol}^{-1}$

\begin{tabular}{|c|c|c|c|c|}
\hline compounds & $\Delta G_{\text {solv,Expt }}^{*}$ & $\Delta G_{\text {solv,SMD }}^{*}$ & $\Delta G_{\text {solv, cluster-SMD }}^{*}$ & $\Delta G_{\text {solv,half-and-half }}^{*}$ \\
\hline \multicolumn{5}{|l|}{ Set A } \\
\hline $\mathrm{Cl}_{2}$ & $-2.0^{a} \pm 0.7$ & 2.0 & 4.5 & 3.2 \\
\hline $\mathrm{Br}_{2}$ & $-7.1^{a} \pm 0.7$ & -4.4 & -3.7 & -4.1 \\
\hline $\mathrm{NF}_{3}$ & $9.8^{a} \pm 0.7$ & 10.8 & 14.1 & 12.4 \\
\hline $\mathrm{H}_{2} \mathrm{O}$ & $-26.4^{b}$ & -28.6 & -25.9 & -27.3 \\
\hline $\mathrm{NH}_{3}$ & $-18.1^{a} \pm 1.3$ & -13.1 & -19.7 & -16.4 \\
\hline $\mathrm{NH}_{2} \mathrm{CH}_{3}$ & $-19.1^{c} \pm 2.5$ & -15.2 & -16.3 & -15.8 \\
\hline $\mathrm{NH}\left(\mathrm{CH}_{3}\right)_{2}$ & $-17.9^{c} \pm 2.5$ & -15.2 & -13.7 & -14.5 \\
\hline \multicolumn{5}{|l|}{ Set B } \\
\hline $\mathrm{NH}_{2} \mathrm{Cl}$ & $-19.0^{a} \pm 4.2$ & -16.3 & -15.7 & -16.0 \\
\hline $\mathrm{NHCl}_{2}$ & $-16.3^{a} \pm 4.2$ & -10.2 & -7.5 & -8.8 \\
\hline $\mathrm{NCl}_{3}$ & $-2.2^{a} \pm 4.2$ & 2.6 & -3.6 & -0.5 \\
\hline $\mathrm{HOCl}$ & $-24.0^{a} \pm 4.2$ & -16.7 & -21.8 & -19.2 \\
\hline \multicolumn{5}{|l|}{ Set A } \\
\hline root mean square error & & 3.3 & 3.8 & 3.2 \\
\hline maximum signed deviation & & $5.0\left(\mathrm{NH}_{3}\right)$ & $6.5\left(\mathrm{Cl}_{2}\right)$ & $5.3\left(\mathrm{Cl}_{2}\right)$ \\
\hline \multicolumn{5}{|l|}{ Set B } \\
\hline root mean square error & & 5.5 & 4.9 & 4.8 \\
\hline maximum signed deviation & & $7.3(\mathrm{HOCl})$ & $8.8\left(\mathrm{NHCl}_{2}\right)$ & $7.5\left(\mathrm{NHCl}_{2}\right)$ \\
\hline
\end{tabular}

${ }^{a}$ Experimental free energies of solvation, based on Henry's law constant values, are taken from Sander's compilation. ${ }^{124} b_{\text {The experimental free }}$ energy of solvation of $\mathrm{H}_{2} \mathrm{O}$ is taken from Marenich et al. ${ }^{125}{ }^{c}$ Estimates of Henry's law constant values were taken from Sander's compilation. ${ }^{126}$

and a single water molecule, in all cases by way of a hydrogen bond between the water $\mathrm{H}$ atom and the halamine $\mathrm{N}$ atom. Natural population analysis indicates that the $\mathrm{N}$ atom has a partial negative charge in all nine inorganic chloramine, bromamine, and bromochloramine structures, ${ }^{101}$ which facilitates this $\mathrm{H}$-bond interaction with nearby aqueous solvent. Our cluster-continuum results assume that this hydrogen-bonded structure is representative of the interaction between a halamine solute and a nearby water molecule in aqueous solvent. We did not see an advantage in increasing the number of explicit water molecules within the cluster-continuum framework. In our trial computations with a test set of neutral halogenated molecules including halamines, clusters containing the solute plus two explicitly modeled water molecules often exhibited shallow potential energy basins, and these clusters typically could occupy multiple stable geometric configurations that differed little in the potential energy (results not shown). We concluded that solvated clusters containing multiple water molecules were not suited to the cluster-continuum approach. The cluster-continuum model assumes that the geometric configuration of the cluster represents the most typical solvent structure near the solute, and the model also assumes that this configuration occupies a well-defined potential energy basin. The cluster-continuum estimate of the free energy of solvation can be obtained by an appropriate thermodynamic cycle, ${ }^{79}$ explained further in the SI. The free energies of solvation computed with the cluster-continuum approaches are referred to as $\Delta G_{\text {solv,cluster-SMD }}^{*}$ and $\Delta G_{\text {solv,cluster-COSMO, depending on the }}^{*}$ implicit model used with the cluster.

To obtain free energies of solvation computed with the cluster-continuum approaches, $\Delta G_{\text {solv,cluster-SMD }}$ and $\Delta G_{\text {solv,cluster-Cosmo, it was necessary to compute several }}^{*}$ quantities, as shown in eqs S4 and S5 in the SI. We conducted a gas phase geometry optimization of a cluster of the solute and one explicit molecule of water with the B2PLYPD/aug-ccpVQZ model chemistry for chloramines, bromamines, bromochloramines, $\mathrm{NH}_{3}, \mathrm{H}_{2} \mathrm{O}, \mathrm{HOCl}, \mathrm{HOBr}, \mathrm{Cl}_{2}, \mathrm{Br}_{2}$, and
$\mathrm{NF}_{3}$. In order to solve consistently the thermodynamic cycle on which the cluster-continuum approach is based, we performed additional gas phase geometry optimizations with B2PLYPD/ aug-cc-pVQZ for all species. Harmonic vibrational frequency analyses were performed with B2PLYPD/aug-cc-pVQZ, used to compute gas phase thermal contributions to the free energies and to confirm the nature of the stationary points on the B2PLYPD potential energy surface. To evaluate the term in SI eq S4, $\Delta G_{\text {solv,SMD }}^{*}\left(X\left(\mathrm{H}_{2} \mathrm{O}\right)\right)$ that is used in the clustercontinuum-SMD approach (and the analogous term in the cluster-continuum-COSMO approach), we also carried out single point energy computations with SMD and COSMO implicit solvent models on gas phase geometries of a cluster of the solute and one explicit molecule of water.

Computational Estimates of Aqueous $p K_{a}$. We estimated aqueous acidity constant $\left(\mathrm{p} K_{a}\right)$ values for the deprotonation of both the neutral species and the cationic conjugate acid ammonium species, for several halamines. It is difficult to estimate absolute $\mathrm{p} K_{a}$ values a priori with theoretical methods. ${ }^{102-104}$ Therefore, we took advantage of the linear free energy relationship (LFER) that is commonly found between experimental and theoretical $\mathrm{p} K_{a}$ values within a family of structurally related acids. ${ }^{95,102,105-107}$ We computed uncorrected quantum chemical acidity constant values according to the equation:

$$
\mathrm{p} K_{\mathrm{a}}^{\text {uncorrected }}=\frac{\Delta G_{\mathrm{aq}}^{\text {dep, uncorrected }}}{2.303 R T}
$$

where $\Delta G_{\mathrm{aq}}^{\mathrm{dep} \text {,uncorrected }}$ is the raw quantum chemical estimate of the free energy of the aqueous deprotonation reaction. To obtain $\Delta G_{\mathrm{aq}}^{\text {dep,uncorrected, }}$ gas phase geometry optimizations, harmonic vibrational frequency analyses, and single point energy computations were conducted with the CBSQB3 ${ }^{108,109}$ composite method. The CBS-QB3 method has previously been shown to give good results for the proton affinities used in $\mathrm{p} K_{\mathrm{a}}$ predictions. $^{95,110-113}$ Solvation free energies were computed with the SMD implicit solvent 
Table 2. Theoretical Standard Free Energies of Formation in Gas Phase $\left(\Delta_{f} G_{\text {gas,Comp }}^{o}\right)$, Theoretical Free Energies of Aqueous Solvation $\left(\Delta G_{\text {solv,half-and-half }}^{*}\right)$, and Theoretical and Experimental Aqueous Standard Free Energies of formation $\left(\Delta_{f} G_{\mathrm{aq}}^{*}\right)$ for Halamines and Related Compounds. Values are in $\mathrm{kJ} \mathrm{mol}^{-1}$

\begin{tabular}{|c|c|c|c|c|}
\hline compounds & $\Delta_{f} G_{\text {gas,Comp }}{ }^{a}$ & $\Delta G_{\text {solv,half-and-half }}^{*}$ & $\Delta_{f} G_{\mathrm{aq}, \mathrm{Comp}}^{*}{ }^{b}$ & $\Delta_{f} G_{\mathrm{aq}, \mathrm{Expt}}^{*}$ \\
\hline $\mathrm{NH}_{2} \mathrm{Cl}$ & $81.1 \pm 1$ & $-16.0 \pm 6$ & $73.1 \pm 6$ & $66.9^{c}, 84.0 \pm 0.4^{d}$ \\
\hline $\mathrm{NHCl}_{2}$ & $174.1 \pm 1$ & $-8.8 \pm 6$ & $173.3 \pm 6$ & $176.6^{c}, 209.2 \pm 1.2^{d}$ \\
\hline $\mathrm{NH}_{2} \mathrm{Br}$ & $96.2 \pm 1$ & $-14.9 \pm 6$ & $89.1 \pm 6$ & $77.0^{c}, 84.3 \pm 0.5^{d}$ \\
\hline $\mathrm{NHBr}_{2}$ & $206.9 \pm 3$ & $-9.4 \pm 6$ & $205.5 \pm 7$ & $181.1^{c}, 203.2 \pm 1.5^{d}$ \\
\hline $\mathrm{NBr}_{3}$ & $306.1 \pm 3$ & $0.4 \pm 6$ & $314.4^{e} \pm 7$ & $295.8^{c}, 329.6 \pm 2.5^{d}$ \\
\hline $\mathrm{NBrCl}_{2}$ & $282.7 \pm 3$ & $2.9 \pm 6$ & $293.5^{e} \pm 7$ & \\
\hline $\mathrm{NBr}_{2} \mathrm{Cl}$ & $292.9 \pm 3$ & $0.3 \pm 6$ & $301.2 \pm 7$ & \\
\hline $\mathrm{NH}_{3}$ & $-15.8 \pm 1$ & $-16.4 \pm 6$ & $-24.3 \pm 6$ & $-26.6^{c}$ \\
\hline $\mathrm{H}_{2} \mathrm{O}$ & $-228.9 \pm 1$ & $-17.3 \pm 6^{f}$ & $-238.3 \pm 6^{f}$ & $-237.2^{c f}$ \\
\hline $\mathrm{HOCl}$ & $-64.8 \pm 1$ & $-19.2 \pm 6$ & $-76.1 \pm 6$ & $-79.9^{c}$ \\
\hline
\end{tabular}

${ }^{a_{T}}$ The gas phase standard free energies of formation at $298 \mathrm{~K}$ were taken from previous high-accuracy theoretical data. ${ }^{76,77} b_{\mathrm{The}}$ error intervals reported for the theoretical standard free energy values are interpreted as error bounds that are expected to contain $95 \%$ of the deviations. ${ }^{c}$ These experimental aqueous standard free energies of formation were taken from Sugam and Helz. ${ }^{69}$ No uncertainty bounds are available. ${ }^{d}$ These experimental aqueous standard free energies of formation were taken from Soulard and co-workers. ${ }^{12}{ }^{e}$ Exceptionally, the cluster-continuum component of the free energies of solvation for $\mathrm{NBrCl}_{2}$ and $\mathrm{NBr}_{3}$ was computed with the aug-cc-pVTZ basis set due to computational costs. ${ }^{f}$ The standard free energy of formation of $\mathrm{H}_{2} \mathrm{O}$ in water is given at the $55.56 \mathrm{M}$ pure liquid standard state instead of the $1 \mathrm{M}$ aqueous standard state.

model and the $M 05^{114} /$ aug-cc-pVTZ model chemistry. The SMD solvent method has been found to perform well in the calculations of free energies of solvation for $\mathrm{p} K_{\mathrm{a}}$ predictions. ${ }^{103,104}$ Further details are provided in the SI. The resulting computed $\mathrm{p} K_{\mathrm{a}}^{\text {uncorrected }}$ values were substituted into the regression functions established by two linear free energy relationships, as explained below.

To construct a theoretical LFER for cationic ammonium functional groups, we fitted a linear regression between theoretical $\mathrm{p} K_{\mathrm{a}}^{\text {uncorrected }}$ values and previously reported experimental $\mathrm{pK}_{\mathrm{a}}$ values for ammonium, ${ }^{115}$ monochlorammonium, ${ }^{4}$ chloromethylammonium, ${ }^{4}$ methylammonium, ${ }^{115}$ dimethylammonium, ${ }^{116}$ bromodimethylammonium, ${ }^{70}$ trimethylammonium, ${ }^{117}$ anilinium, ${ }^{118}$ 2-chloranilinium, ${ }^{118}$ 2-bromoanilinium, ${ }^{118} \mathrm{~N}$-methylanilinium, ${ }^{118}$ hydroxylammonium, ${ }^{119}$ protonated hydrazine, ${ }^{120}$ carbamidium (protonated urea), ${ }^{121}$ acetamidium (protonated acetamide), ${ }^{121}$ and thiocarbamidium (protonated thiourea). ${ }^{121}$ This LFER was used to estimate the computed $\mathrm{p} K_{\mathrm{a}}$ values of the cationic species monobromammonium, dibromammonium, dichlorammonium, bromomethylammonium, chloromethylammonium, dibromomethylammonium, and dichloromethylammonium.

To construct a theoretical LFER describing the acidity constant of the neutral amine functional group, we conducted a linear regression between theoretical $\mathrm{p} K_{\mathrm{a}}^{\text {uncorrected }}$ values and previously reported experimental $\mathrm{p} K_{\mathrm{a}}$ data of hydrazoic acid, ${ }^{122}$ acetamide, ${ }^{122}$ sulfamide, ${ }^{123}$ and trifluoromethanesulfamide. ${ }^{122}$ The resulting LFER was employed to estimate the computed $\mathrm{pK}_{\mathrm{a}}$ values of monochloramine, monobromamine, dichloramine, dibromamine, and bromochloramine.

\section{RESULTS AND DISCUSSION}

Evaluation of Solvent Models for Halogen Species and Amines. We evaluated six different solvent modeling approaches for their abilities to predict the free energies of solvation for species that are structurally related to the halamines. Four implicit solvent models (SMD, CPCM, $\mathrm{PCM}$, and COSMO) and two cluster-continuum approaches were applied to $\mathrm{Cl}_{2}, \mathrm{Br}_{2}, \mathrm{NF}_{3}, \mathrm{NH}_{3}, \mathrm{H}_{2} \mathrm{O}, \mathrm{NH}_{2} \mathrm{CH}_{3}$ and $\mathrm{NH}\left(\mathrm{CH}_{3}\right)_{2}$ which we denoted as test set A (Table 1 ). Experimental Henry's law constants are available for these seven species (SI Table S1), ${ }^{124-126}$ with corresponding experimental free energy of solvation $\left(\Delta G_{\text {solv,Expt }}^{*}\right)$ values that are considered to have uncertainties ranging from $\pm 0.7 \mathrm{~kJ}$ $\mathrm{mol}^{-1}$ to $\pm 2.5 \mathrm{~kJ} \mathrm{~mol}^{-1}$ (Table 1 ). We also tested the solvent

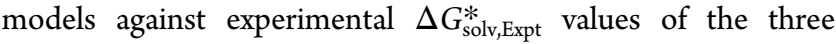
chloramines and of hypochlorous acid, which have been assigned larger uncertainties of $\pm 4.2 \mathrm{~kJ} \mathrm{~mol}^{-1}$. ${ }^{124}$

The SMD model and cluster-continuum-SMD approaches exhibit root-mean-square errors (RMSE) of $3.3 \mathrm{~kJ} \mathrm{~mol}^{-1}$ and $3.8 \mathrm{~kJ} \mathrm{~mol}^{-1}$, respectively, with respect to $\Delta G_{\mathrm{solv}, \text { Expt }}^{*}$ values for set A (Table 1). For compound set B, which contains compounds having more uncertain experimental values, the two models produced larger RMSE values of $5.5 \mathrm{~kJ} \mathrm{~mol}^{-1}$ and $4.9 \mathrm{~kJ} \mathrm{~mol}^{-1}$, respectively. The average unsigned error observed for SMD with test set $\mathrm{A}\left(3.1 \mathrm{~kJ} \mathrm{~mol}^{-1}\right)$ is very similar to the average unsigned errors that ranged from 2.5 to $3.8 \mathrm{~kJ} \mathrm{~mol}^{-1}$ (depending on the DFT method) reported elsewhere ${ }^{86}$ for SMD with a very large test set of small neutral molecules in water. The COSMO, CPCM, and PCM models produced worse results for this chemical test set (SI Table S3), and these models were thus viewed as less appropriate for investigating the solvation of halamines in water.

Based on the above results, it is difficult to distinguish whether the SMD implicit model or the cluster-continuumSMD approach would perform the best for estimating the free energies of solvation of bromamines, chloramines, and bromochloramines. Closer inspection of Table 1 results is revealing. Compared to the conventional SMD implicit model, the addition of an explicit water (i.e., cluster-continuum-SMD approach) improves, but "overcorrects", the predictions of Henry's law constants for the polar molecules $\mathrm{NH}_{3}$ and $\mathrm{H}_{2} \mathrm{O}$. In contrast, the cluster-continuum-SMD approach appears to worsen slightly the results for the halogen-containing species $\left(\mathrm{Cl}_{2}, \mathrm{Br}_{2}, \mathrm{NF}_{3}\right)$, compared to conventional SMD. Taken together, these results suggest that a "half-and-half" approach, 
Table 3. Equilibrium Constants $\left(\log K_{\mathrm{aq}}\right)$ for Reactions Leading to Halamines in Water: Computational and Experimental Estimates

\begin{tabular}{|c|c|c|c|c|}
\hline$\#$ & reactions & $\log K_{\mathrm{aq}}^{\mathrm{Comp} a}$ & $\log K_{\mathrm{aq}}^{\mathrm{eq}} \cdot 9 b$ & $\log K_{\mathrm{aq}}^{\mathrm{Expt}}$ \\
\hline & chloramines & & & \\
\hline 1 & $\mathrm{NH}_{3, \mathrm{aq}}+\mathrm{HOCl}_{\mathrm{aq}} \stackrel{\mathrm{K}_{1}}{\rightleftharpoons} \mathrm{NH}_{2} \mathrm{Cl}_{\mathrm{aq}}+\mathrm{H}_{2} \mathrm{O}_{\mathrm{l}}$ & $11.4 \pm 1.1$ & $10.6 \pm 0.8$ & $11.3^{c}, 8.2^{d}$ \\
\hline 2 & $\mathrm{NH}_{2} \mathrm{Cl}_{\mathrm{aq}}+\mathrm{HOCl}_{\mathrm{aq}} \stackrel{K_{2}}{\rightleftharpoons} \mathrm{NHCl}_{2, \mathrm{aq}}+\mathrm{H}_{2} \mathrm{O}_{\mathrm{l}}$ & $10.9 \pm 1.1$ & $10.7 \pm 0.8$ & $8.7^{c}$ \\
\hline \multirow[t]{2}{*}{3} & $\mathrm{NHCl}_{2, \mathrm{aq}}+\mathrm{HOCl}_{\mathrm{aq}} \stackrel{K_{3}}{\rightleftharpoons} \mathrm{NCl}_{3, \mathrm{aq}}+\mathrm{H}_{2} \mathrm{O}_{\mathrm{l}}$ & $10.7 \pm 1.1$ & $8.7 \pm 0.8$ & $4.7^{c}, 8.2^{e}, 7.5^{d}$ \\
\hline & bromamines & & & \\
\hline 4 & $\mathrm{NH}_{3 \mathrm{aq}}+\mathrm{HOBr}_{\mathrm{aq}} \stackrel{\mathrm{K}_{4}}{\rightleftharpoons} \mathrm{NH}_{2} \mathrm{Br}_{\mathrm{aq}}+\mathrm{H}_{2} \mathrm{O}_{1}$ & $9.3 \pm 1.1$ & & $10.5^{f}$ \\
\hline 5 & $\mathrm{NH}_{2} \mathrm{Br}_{\mathrm{aq}}+\mathrm{HOBr}_{\mathrm{aq}} \stackrel{K_{5}}{\rightleftharpoons} \mathrm{NHBr}_{2, \mathrm{aq}}+\mathrm{H}_{2} \mathrm{O}_{1}$ & $8.8 \pm 1.2$ & & $8.7^{f}$ \\
\hline \multirow[t]{2}{*}{6} & $\mathrm{NHBr}_{2, \mathrm{aq}}+\mathrm{HOBr}_{\mathrm{aq}} \stackrel{\mathrm{K}_{6}}{\rightleftharpoons} \mathrm{NBr}_{3, \mathrm{aq}}+\mathrm{H}_{2} \mathrm{O}_{1}$ & $10.1^{g} \pm 1.2$ & & $6.7^{f}$ \\
\hline & bromochloramines & & & \\
\hline 7 & $\mathrm{NH}_{2} \mathrm{Br}_{\mathrm{aq}}+\mathrm{HOCl}_{\mathrm{aq}} \stackrel{K_{7}}{\rightleftharpoons} \mathrm{NHBrCl}_{\mathrm{aq}}+\mathrm{H}_{2} \mathrm{O}_{1}$ & $11.8 \pm 1.2$ & & \\
\hline 8 & $\mathrm{NH}_{2} \mathrm{Cl}_{\mathrm{aq}}+\mathrm{HOBr}_{\mathrm{aq}} \stackrel{K_{8}}{\rightleftharpoons} \mathrm{NHBrCl}_{\mathrm{aq}}+\mathrm{H}_{2} \mathrm{O}_{\mathrm{l}}$ & $9.8 \pm 1.2$ & & \\
\hline 9 & $\mathrm{NHBrCl}_{\mathrm{aq}}+\mathrm{HOCl}_{\mathrm{aq}} \stackrel{K_{9}}{\rightleftharpoons} \mathrm{NBrCl}_{2, \mathrm{aq}}+\mathrm{H}_{2} \mathrm{O}_{1}$ & $9.2^{g} \pm 1.2$ & & \\
\hline 10 & $\mathrm{NHBrCl}_{\mathrm{aq}}+\mathrm{HOBr}_{\mathrm{aq}} \stackrel{K_{10}}{\rightleftharpoons} \mathrm{NBr}_{2} \mathrm{Cl}_{\mathrm{aq}}+\mathrm{H}_{2} \mathrm{O}_{\mathrm{l}}$ & $8.7 \pm 1.2$ & & \\
\hline 11 & $\mathrm{NHCl}_{2, \mathrm{aq}}+\mathrm{HOBr}_{\mathrm{aq}} \stackrel{K_{11}}{\rightleftharpoons} \mathrm{NBrCl}_{2, \mathrm{aq}}+\mathrm{H}_{2} \mathrm{O}_{1}$ & $8.1^{g} \pm 1.2$ & & \\
\hline \multirow[t]{2}{*}{12} & $\mathrm{NHBr}_{2, \mathrm{aq}}+\mathrm{HOCl}_{\mathrm{aq}} \stackrel{K_{12}}{\rightleftharpoons} \mathrm{NBr}_{2} \mathrm{Cl}_{\mathrm{aq}}+\mathrm{H}_{2} \mathrm{O}_{1}$ & $11.7 \pm 1.2$ & & \\
\hline & disproportionation reactions & & & \\
\hline 13 & $\mathrm{NH}_{2} \mathrm{Cl}_{\mathrm{aq}}+\mathrm{NH}_{2} \mathrm{Cl}_{\mathrm{aq}} \stackrel{K_{13}}{\rightleftharpoons} \mathrm{NHCl}_{2, \mathrm{aq}}+\mathrm{NH}_{3, \mathrm{aq}}{ }^{h}$ & $-0.5 \pm 1.1$ & $0.1 \pm 0.8$ & $-2.6^{i}$ \\
\hline 14 & $\mathrm{NH}_{2} \mathrm{Br}_{\mathrm{aq}}+\mathrm{NH}_{2} \mathrm{Br}_{\mathrm{aq}} \stackrel{K_{14}}{\rightleftharpoons} \mathrm{NHBr}_{2, \mathrm{aq}}+\mathrm{NH}_{3, \mathrm{aq}}^{j}$ & $-0.5 \pm 1.2$ & & $0.5^{k}$ \\
\hline 15 & $\mathrm{NH}_{2} \mathrm{Cl}_{\mathrm{aq}}+\mathrm{NH}_{2} \mathrm{Br}_{\mathrm{aq}} \stackrel{K_{15}}{\rightleftharpoons} \mathrm{NHBrCl}_{\mathrm{aq}}+\mathrm{NH}_{3, \mathrm{aq}}$ & $0.4 \pm 1.2$ & & \\
\hline 16 & $\mathrm{NHBrCl}_{\mathrm{aq}}+\mathrm{HOCl}_{\mathrm{aq}} \stackrel{K_{16}}{\rightleftharpoons} \mathrm{NHCl}_{2, \mathrm{aq}}+\mathrm{HOBr}_{\mathrm{aq}}$ & $1.1 \pm 1.2$ & & \\
\hline 17 & $\mathrm{NHBrCl}_{\mathrm{aq}}+\mathrm{HOBr}_{\mathrm{aq}} \stackrel{K_{17}}{\rightleftharpoons} \mathrm{NHBr}_{2, \mathrm{aq}}+\mathrm{HOCl}_{\mathrm{aq}}$ & $-3.0 \pm 1.2$ & & \\
\hline 18 & ${ }_{2} \mathrm{NH}_{2} \mathrm{Cl}_{\mathrm{aq}}+\mathrm{Br}_{\mathrm{aq}}^{-}+\mathrm{H}_{\mathrm{aq}}^{+} \stackrel{K_{18}}{\rightleftharpoons} \mathrm{NHBrCl}_{\mathrm{aq}}+\mathrm{NH}_{4, \mathrm{aq}}^{+}+\mathrm{Cl}_{\mathrm{aq}}^{-}$ & $12.0^{l}$ & & \\
\hline
\end{tabular}

${ }^{a_{T}}$ These estimates were calculated using eqs 6 and 7. Uncertainty bounds are assigned such that the prediction is expected to contain the correct experimental value in $95 \%$ of cases. ${ }^{b}$ These estimates were calculated using eq 9. ${ }^{c}$ This $\log K_{\mathrm{aq}}^{\text {Expt }}$ value was obtained from Morris and Isaac's fitting

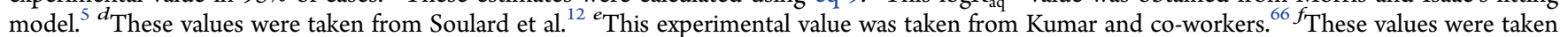

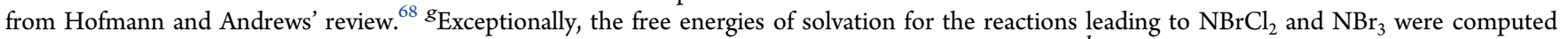
with the aug-cc-pVTZ basis set, due to the computational cost of computations with larger basis sets. ${ }^{h}$ This reaction can take place by two parallel pathways: a neutral uncatalyzed pathway and also an acid-catalyzed pathway. The computed and experimental equilibrium constant values reported here refer to the uncatalyzed reaction. ${ }^{128}{ }^{i}$ These values were taken from Morris and Isaac's work. ${ }^{5}{ }^{3}$ This reaction can take place by two parallel pathways: a neutral uncatalyzed pathway and also an acid-catalyzed pathway. The computed and experimental equilibrium constant values reported

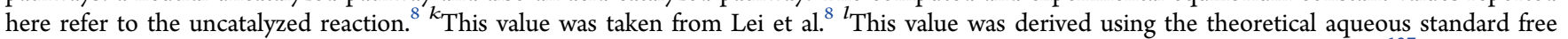
energy of formation for $\mathrm{NH}_{2} \mathrm{Cl}$ and $\mathrm{NHBrCl}$ (Table 2) and the previously reported experimental standard free energy of formation ${ }^{127}$ for $\mathrm{H}_{\mathrm{aq}}^{+}, \mathrm{Br}_{\mathrm{aq}}^{-}$, $\mathrm{NH}_{\mathrm{aq}}^{+}$, and $\mathrm{Cl}_{\mathrm{aq}}^{-}$.

formulated as an average of the predictions by both solvent models, would produce the most accurate results overall for the related molecules, chloramines and bromamines. The "half-andhalf" approach exhibits a RMSE of $3.2 \mathrm{~kJ} \mathrm{~mol}^{-1}$ in the free energies of solvation of set A. Based on these considerations, we propose that the error bounds expected to contain $95 \%$ of the deviations can be approximated by $2 \times$ RMSE found for the free energy of solvation data, and thus we assign an error of $6 \mathrm{~kJ}$ $\mathrm{mol}^{-1}$ to the free energy of solvation values estimated from the "half-and-half" approach for chloramines, bromamines, and bromochloramines (Table 2).
Estimated Aqueous Standard Free Energies of Formation for Chloramines, Bromamines, and Bromochloramines. We estimated aqueous standard free energies of formation of halamines and related compounds (Table 2) based on theoretically determined standard free energies of formation in gas phase, $\Delta_{f} G_{\mathrm{gas}, \mathrm{Comp}}^{\mathrm{o}}(X)$, and computationally estimated free energies of solvation, $\Delta G_{\text {solv,half-and-half }}^{*}(X)$, according to

$$
\Delta_{f} G_{\mathrm{aq}, \mathrm{Comp}}^{*}(X)=\Delta_{f} G_{\mathrm{gas}, \mathrm{Comp}}^{o}(X)+\Delta G_{\mathrm{solv}, \text { half-and-half }}^{*}(X)+\Delta G^{o \rightarrow *}
$$


Theoretical benchmark $\Delta_{f} G_{\text {gas,Comp }}^{\mathrm{o}}(X)$ values at 1 atm standard state were taken from recently published data. ${ }^{76,77}$ The $\Delta G_{\text {solv,half-and-half }}^{*}(X)$ values were obtained from an average of the SMD implicit solvent model results and the clustercontinuum-SMD results as discussed in the previous section. The term $\Delta G^{\circ \rightarrow *}$ represents the free energy required to transfer a molecule from the gas phase 1 atm standard state to the aqueous $1 \mathrm{M}$ standard state. ${ }^{78}$

For computational $\Delta_{f} G_{\mathrm{aq}, \text { Comp }}^{*}$ data, we assigned uncertainty bounds such that the computational predictions are expected to contain the correct experimental value in $95 \%$ of cases, as follows. In a previous study, we attributed an uncertainty of $1 \mathrm{~kJ}$ $\mathrm{mol}^{-1}$ to the $\Delta_{f} G_{\mathrm{gas}, \mathrm{Comp}}^{\mathrm{o}}$ of the three chloramines and of monobromamine, whereas we assigned an uncertainty of $3 \mathrm{~kJ}$ $\mathrm{mol}^{-1}$ to the $\Delta_{f} G_{\mathrm{gas}, \mathrm{Comp}}^{\mathrm{o}}$ values of bromochloramines, dibromamine, and tribromamine, based on comparisons between theoretical and experimental data discussed in that paper and citations therein. $^{76,77}$ Based on the results discussed in the previous section (Table 1 ), the $\Delta G_{\text {solv,half-and-half values predicted }}^{*}$ with the "half-and-half" approach (an average of the SMD and the cluster-continuum-SMD values) are assigned an uncertainty of $6 \mathrm{~kJ} \mathrm{~mol}^{-1}$. Based on propagation of error (SI eqs S11 and S12), we estimated an error of $6 \mathrm{~kJ} \mathrm{~mol}^{-1}$ for the $\Delta_{f} G_{\mathrm{aq}, \mathrm{Comp}}^{*}$ values of chloramines, $\mathrm{NH}_{3}, \mathrm{H}_{2} \mathrm{O}, \mathrm{HOCl}, \mathrm{HOBr}$, and $\mathrm{NH}_{2} \mathrm{Br}$, and an error of $7 \mathrm{~kJ} \mathrm{~mol}^{-1}$ for the $\Delta_{f} G_{\mathrm{aq}, \text { Comp }}^{*}$ values of dibromamine, tribromamine, and the three bromochloramines. For the well-characterized molecules $\mathrm{NH}_{3}$ and $\mathrm{H}_{2} \mathrm{O}$, the theoretical $\Delta_{f} G_{\text {aq,Comp }}^{*}$ values differ from the experimental $\Delta_{f} G_{\text {aq,Expt }}^{*}$ values by only 2.3 and $1.1 \mathrm{~kJ} \mathrm{~mol}^{-1}$, respectively (Table 2). However, for the chloramines and bromamines, there is less consistent agreement between theoretical and experimental results, and some of the previously reported experimental data show large discrepancies from one another. A critical discussion of these different data sets is explored in the following section on aqueous equilibrium constants.

Aqueous Equilibrium Constants of Reactions that Produce Chloramines, Bromamines, and Bromochloramines. Despite the wide importance of halamines in drinking water treatment, equilibrium constants have not been wellconstrained for many of the reactions responsible for their occurrence. We determined equilibrium constants $\left(K_{\mathrm{aq}}^{\text {Comp }}\right)$ for several important reactions, based on theoretical $\Delta_{f} G_{\text {aq, Comp }}^{*}$ data (Table 2), and we compared these $K_{\mathrm{aq}}^{\text {Comp }}$ values to previously reported experimental estimates, where available.

For a reaction in aqueous solution, we can evaluate the aqueous free energy of reaction, $\Delta G_{a q}^{*}$ :

$$
\Delta G_{\mathrm{aq}}^{*}=\Sigma_{i} \nu_{i} \Delta_{f} G_{\mathrm{aq}}^{*}\left(X_{i}\right)
$$

where the $\nu_{i}$ is the stoichiometric coefficient of molecule $X_{i}$, and $\Delta_{f} G_{\mathrm{aq}}^{*}\left(X_{i}\right)$ is the aqueous standard Gibbs free energy of formation for species $X_{i}$ at $1 \mathrm{M}$ standard state. For those reactions that generate water as a product, we applied a standard state conversion so that $\mathrm{H}_{2} \mathrm{O}$ is at the liquid water $(55.56 \mathrm{M})$ standard state (Table 2). ${ }^{78}$ Further details on standard state conversion factors are provided in the SI. The computed aqueous equilibrium constant for a given reaction is obtained by

$$
K_{\mathrm{aq}}=\exp \left(\frac{-\Delta G_{\mathrm{aq}}^{*}}{R T}\right)
$$

Theoretical equilibrium constant data, $K_{\mathrm{aq}}^{\text {Comp }}$, reveal that reactions of ammonia with $\mathrm{HOCl}$ and $\mathrm{HOBr}$ that produce mono-, di-, and trihalogenated species are highly favorable, with $\log K_{\mathrm{aq}}^{\text {Comp }}$ values ranging from 8.1 to 11.8 (reactions $1-12$, Table 3). The considered disproportionation reactions that involved neutral species (reactions 13-17, Table 3) were found to have $\log K_{\mathrm{aq}}^{\mathrm{Comp}}$ values ranging from -3.0 to 1.1 . Based on the uncertainties ascribed to $\Delta_{f} G_{\mathrm{aq}, \text { Comp }}^{*}$ values (Table 2), we assigned an error of \pm 1.1 to \pm 1.2 logarithmic unit to $\log K_{\mathrm{aq}}^{\mathrm{Comp}}$ values, depending on the reaction.

In previous reports, equilibrium constants have been estimated based on experimental data for several reactions that produce halamines. Morris and Isaac reported an aqueous equilibrium constant value, $K_{\mathrm{aq}}^{\mathrm{Ext}}$, of $10^{11.3}$ for the reaction leading to $\mathrm{NH}_{2} \mathrm{Cl}$ (reaction 1, Table 3), a value of $10^{8.7}$ for the reaction leading to $\mathrm{NHCl}_{2}$ (reaction 2), and a value of $10^{4.7}$ for the reaction leading to $\mathrm{NCl}_{3}$ (rection 3). ${ }^{5}$ However, Kumar and co-workers ${ }^{66}$ proposed an estimate of $10^{8.2}$ for $K_{3}, 4$ orders of magnitude higher than the value suggested by Morris and Isaac. The equilibrium constants reported by Morris and Isaac ${ }^{5}$ and by Kumar et al. ${ }^{66}$ were deduced based on the measurements of forward and reverse rate constants for these reactions. This discrepancy between different studies reflects the difficulties encountered during the measurements of rate constants used to deduce the equilibrium constants of these reactive species in water. Hofmann and Andrews estimated aqueous equilibrium constants for the production of bromamines, ${ }^{68}$ based on estimated standard free energies of formation of bromamines taken from Sugam and Helz's work. ${ }^{69}$ The aqueous equilibrium constant of one disproportionation reaction was estimated: the disproportionation of two molecules of monochloramine to form dichloramine (reaction 13). ${ }^{5}$ The origins of some of these equilibrium constant data are discussed further in the section about rate constants, below.

We compared our theoretical aqueous equilibrium constant values, $K_{\mathrm{aq}}^{\text {Comp }}$, with available estimates obtained from reported experimental data, $K_{\mathrm{aq}}^{\mathrm{Expt}}$. We found good agreement between our theoretical aqueous equilibrium constants and previously reported experimental values for the reactions leading to monochloramine (reaction 1), monobromamine (reaction 4), and dibromamine (reaction 5): the experimental and computational equilibrium constants for these reactions agree within 1 order of magnitude, which falls within the error bounds of the theoretical values (Table 3 ). We viewed that the experimental equilibrium constants reported for reactions 1 and 4 were reliable values, since both the forward and reverse rate constants can be measured under well-controlled conditions for these two reactions. We consider these findings as a validation of the theoretical approach, further confirming the validations of $\Delta_{f} G_{\text {gas,Comp }}^{\text {o }}, \Delta G_{\text {solv,half-and-half, }}^{*}$ and $\Delta_{f} G_{\text {aq, Comp }}^{*}$ data, discussed above. However, the agreement between experimental and theoretical results decreases substantially for the reactions that produce dichloramine (reaction 2, Table 3), trichloramine (reaction 3), and tribromamine (reaction 6), as well as the disproportionation reaction 13 . Theoretical $K_{\mathrm{aq}}^{\text {Comp }}$ values for these reactions are $\sim 2$ to 5 orders of magnitude higher than the experimental equilibrium constants. The discrepancies observed for reactions 2, 3, 6, and 13 might be attributed to the difficulty in performing well-controlled experiments on these species. ${ }^{5}$ The experimental equilibrium constant values for reactions $2,3,6$, and 13 are not direct measurements; rather, they are constrained from kinetic and thermodynamic models that involve multiple reactions. ${ }^{5,69}$ 
Table 4. New Estimates of Reverse Rate Constant Values for Selected Reactions that Produce Chloramines, Bromamines, and Bromochloramines

\begin{tabular}{|c|c|c|c|c|}
\hline$\#^{a}$ & reaction & $k_{f, \mathrm{rxn}}^{\mathrm{Expt}}$ & $k_{r, \mathrm{rxn}}^{\mathrm{eq} .10 b}$ & $k_{r, \mathrm{xnn}}^{\mathrm{Expt}}$ \\
\hline 1 & $\mathrm{NH}_{3, \mathrm{aq}}+\mathrm{HOCl}_{\mathrm{aq}} \underset{\mathrm{k}_{-1}}{\stackrel{\mathrm{k}_{1}}{\rightleftharpoons}} \mathrm{NH}_{2} \mathrm{Cl}_{\mathrm{aq}}+\mathrm{H}_{2} \mathrm{O}_{1}$ & $4.2 \times 10^{6} \mathrm{M}^{-1} \mathrm{~s}^{-1 c}$ & $2 \times 10^{-5} \mathrm{~s}^{-1}$ & $2.1 \times 10^{-5} \mathrm{~s}^{-1 c}$ \\
\hline 2 & $\mathrm{NH}_{2} \mathrm{Cl}_{\mathrm{aq}}+\mathrm{HOCl}_{\mathrm{aq}} \underset{k_{-2}}{\stackrel{k_{2}}{\rightleftharpoons}} \mathrm{NHCl}_{2, \mathrm{aq}}+\mathrm{H}_{2} \mathrm{O}_{1}$ & $3.5 \times 10^{2} \mathrm{M}^{-1} \mathrm{~s}^{-1 c}$ & $5 \times 10^{-9} \mathrm{~s}^{-1}$ & $7.6 \times 10^{-7} \mathrm{~s}^{-1 c}$ \\
\hline 4 & $\mathrm{NH}_{3, \mathrm{aq}}+\mathrm{HOBr}_{\mathrm{aq}} \underset{k_{-4}}{\stackrel{k_{4}}{\rightleftharpoons}} \mathrm{NH}_{2} \mathrm{Br}_{\mathrm{aq}}+\mathrm{H}_{2} \mathrm{O}_{1}$ & $7.50 \pm 0.4 \times 10^{7} \mathrm{M}^{-1} \mathrm{~s}^{-1 d}$ & $4 \times 10^{-2} \mathrm{~s}^{-1}$ & \\
\hline 8 & $\mathrm{NH}_{2} \mathrm{Cl}_{\mathrm{aq}}+\mathrm{HOBr}_{\mathrm{aq}} \underset{k_{-8}}{\stackrel{k_{8}}{\rightleftharpoons}} \mathrm{NHBrCl}_{\mathrm{aq}}+\mathrm{H}_{2} \mathrm{O}_{\mathrm{l}}$ & $2.86 \pm 0.06 \times 10^{5} \mathrm{M}^{-1} \mathrm{~s}^{-1 e}$ & $5 \times 10^{-5} \mathrm{~s}^{-1}$ & \\
\hline 13 & $\mathrm{NH}_{2} \mathrm{Cl}_{\mathrm{aq}}+\mathrm{NH}_{2} \mathrm{Cl}_{\mathrm{aq}} \underset{k_{-13}}{\stackrel{k_{13}}{\rightleftharpoons}} \mathrm{NHCl}_{2, \mathrm{aq}}+\mathrm{NH}_{3, \mathrm{aq}} f$ & $5.6 \times 10^{-2} \mathrm{M}^{-1} \mathrm{~s}^{-1 c}$ & $0.2 \mathrm{M}^{-1} \mathrm{~s}^{-1}$ & $24 \mathrm{M}^{-1} \mathrm{~s}^{-1 c}$ \\
\hline
\end{tabular}

${ }^{a}$ Reaction number is taken from Table $3 .{ }^{b}$ Estimates were calculated using eq $10 .{ }^{c}$ Experimental values were taken from Morris and Isaac's work. ${ }^{5}$ ${ }^{d}$ Experimental value was taken from Wajon and Morris. ${ }^{11} e$ Experimental value was taken from Gazda and Margerum. ${ }^{51} f_{\text {This reaction can take place }}$ by two parallel pathways: a neutral uncatalyzed pathway and also an acid-catalyzed pathway. The calculated and experimental rate constant values reported here refer to the uncatalyzed reaction. ${ }^{28}$

Based on the expected uncertainty of our theoretical data, we infer that the theoretical equilibrium constant values have higher confidence than the previously reported experimental estimates for the reactions $2,3,6$, and 13 . These findings imply that the reactions that produce dichloramine, trichloramine, and tribromamine are more thermodynamically favorable than was previously estimated. Therefore, under circumneutral conditions conducive to the production of chloramines and/ or bromamines, the equilibrium concentrations of the dichloramine, trichloramine, and tribromamine species are higher than what previous models have suggested.

For further validation of our theoretical equilibrium constant values, $K_{\mathrm{aq}}^{\mathrm{Comp}}$, we compare them to a second set of estimates, referred to as $K_{\mathrm{aq}}^{\mathrm{eq} .9}$. These values were determined based on theoretical $\Delta_{f} G_{\text {gas,Comp }}^{\mathrm{o}}$ values (Table 2) combined with previously reported experimental Henry's law constants, where available:

$$
K_{\mathrm{aq}}^{\mathrm{eq} \cdot 9}=\exp \left(\frac{-\Sigma_{i} \nu_{i}\left(\Delta_{f} G_{\mathrm{gas}, \mathrm{Comp}}^{o}\left(X_{i}\right)+\Delta G_{\mathrm{sol}, \mathrm{Expt}}^{*}\left(X_{i}\right)+\Delta G^{o \rightarrow *}\right)}{R T}\right)
$$

Based on available experimental reports of Henry's law constants, we determined the $K_{\mathrm{aq}}^{\mathrm{eq} .9}$ for reactions involving chloramines (reactions $1,2,3$, and 13, Table 3 ). We assigned an uncertainty of $0.8 \log$ unit to the $\log K_{\mathrm{aq}}^{\text {eq. }} \cdot$ values based on the uncertainty of $1 \mathrm{~kJ} \mathrm{~mol}^{-1}$ attributed to $\Delta_{f} G_{\text {gas,Comp }}^{\mathrm{o}}$ and the uncertainty of $4.2 \mathrm{~kJ} \mathrm{~mol}^{-1}$ associated with the $\Delta G_{\text {solv,Expt }}^{*}$.

The resulting $K_{\mathrm{aq}}^{\mathrm{eq} .9}$ values for reactions 1,2 , and 13 (Table 3) all exhibit good agreement with $K_{\mathrm{aq}}^{\text {Comp }}$ estimates obtained from the theoretical $\Delta G_{\mathrm{aq}}^{*}$ given by eq 6 , which offers mutual validation of these two data sets. Exceptionally, the $K_{\mathrm{aq}}^{\mathrm{eq} .9}$ value for reaction 3 disagrees with $K_{\mathrm{aq}}^{\text {Comp }}$ by a factor of 100 . This discrepancy for reaction 3 is attributed to additive disagreement between $\Delta G_{\text {solv, Expt }}^{*}$ and $\Delta G_{\text {solv,half-and-half }}^{*}$ values for the compounds $\mathrm{HOCl}$ and $\mathrm{NHCl} 2$ (Table 1), which propagates into the free energies used to determine $K_{\mathrm{aq}}^{\text {eq. }}$ (eq 9) and $K_{\mathrm{aq}}^{\mathrm{Comp}}$ (eq 6), respectively. In contrast, the $K_{\mathrm{aq}}^{\text {eq.9 }}$ values for reactions 2 , 3 , and 13 are up to 4 orders of magnitude higher than the reported experimental estimates. These data further confirm the above conclusion that the theoretical estimates of the present study improve upon some of the previously reported experimental estimates for reactions 2, 3, 6, and 13 .

We also estimated the aqueous equilibrium constant for the disproportionation reaction between two molecules of $\mathrm{NH}_{2} \mathrm{Cl}$ and $\mathrm{Br}^{-}$(reaction 18, Table 3). We combined theoretical aqueous standard free energies of formation for the $\mathrm{NH}_{2} \mathrm{Cl}$ and $\mathrm{NHBrCl}$ species from Table 2 together with reported experimental aqueous standard free energies of formation ${ }^{127}$ for the remaining compounds, $\mathrm{H}^{+}, \mathrm{Br}^{-}, \mathrm{NH}_{4}^{+}$, and $\mathrm{Cl}^{-}$. Since we could not find uncertainty bounds for the experimental aqueous standard free energy of formation data, we did not assign an uncertainty value to this equilibrium constant.

\section{IMPLICATIONS FOR REACTION RATE CONSTANTS}

Based on the theoretical aqueous equilibrium constants presented here (Table 3), we can re-evaluate rate constant data for some of the decomposition reactions for chloramines, bromamines, and bromochloramines. For this purpose, we took advantage of the relationship between the reaction equilibrium constant, the forward reaction rate constant, and the reverse reaction rate constant: ${ }^{129}$

$$
k_{\mathrm{r}}^{\mathrm{eq} \cdot 10}=\frac{k_{f}^{\text {Expt }}}{K_{\mathrm{aq}}^{\text {Comp }}}
$$

We assumed that the forward experimental rate constant $\left(k_{\mathrm{f}}^{\text {Expt }}\right)$ had been determined reliably by experiment in previous reports for the five reactions shown in Table 4. Equilibrium constant values $\left(K_{\mathrm{aq}}^{\mathrm{Comp}}\right)$ were taken from our theoretical results (Table 3). We compared our theoretically supported estimates of the reverse rate constant for the production of monochloramine, $k_{-1}^{\text {eq. } 10}$, to the previously reported experimental value, $k_{-1}^{\text {Expt }}$. By way of eq 10 , our theoretical estimate, $k_{-1}^{\text {eq.10 }}=2 \times 10^{-5} \mathrm{~s}^{-1}$, is in good agreement with the experimental value, $k_{-1}^{\mathrm{Expt}}=2.1 \times 10^{-5}$ $\mathrm{s}^{-1}$. The agreement between $k_{-1}^{\text {Expt }}$ and $k_{-1}^{\text {eq. } 10}$ is consistent with the observed agreement between $K_{1}^{\mathrm{Comp}}$ and $K_{1}^{\mathrm{Expt}}$ for this reaction (Table 3 ). For the chlorination reaction of monochloramine to form dichloramine, we determined a theoretical reverse rate constant of $k_{-2}^{\text {eq. } 10}=5 \times 10^{-9} \mathrm{~s}^{-1}$, based on the reported experimental value of the forward reaction (Table 4) 


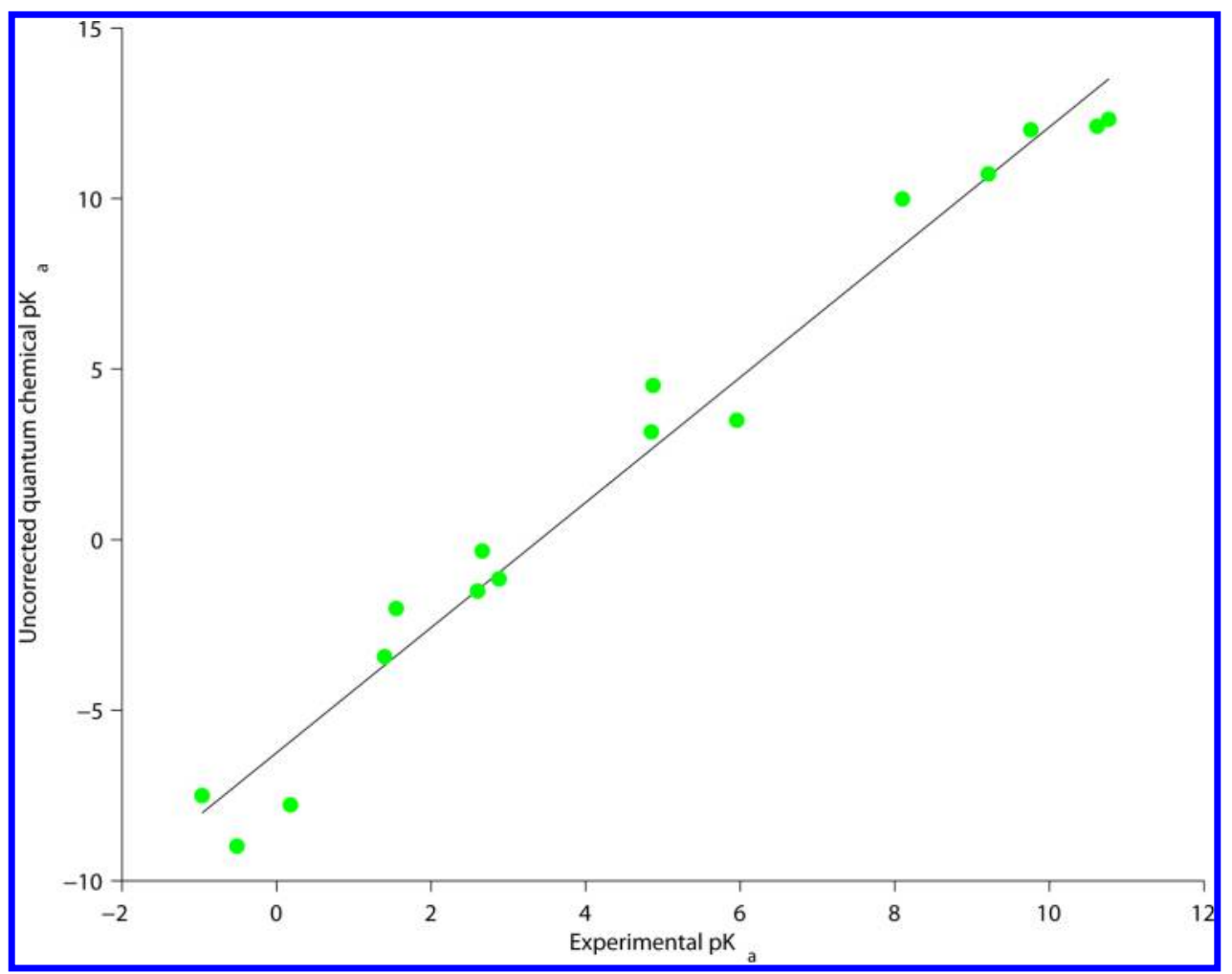

Figure 1. Correlation between the experimental $\mathrm{p} K_{a}$ values and the uncorrected quantum chemical $\mathrm{p} K_{a}^{\text {uncorrected }}$ results for the ammonium functional group of several compounds, including some halamines for which data are available (SI Table S5).

and the theoretical equilibrium constant, $K_{\mathrm{aq}}^{\mathrm{Comp}}=10^{10.9 \pm 1.1}$ (Table 3). The resulting value of $5 \times 10^{-9} \mathrm{~s}^{-1}$ for the rate constant of the hydrolysis of dichloramine, $k_{-2}^{\text {eq.10 }}$, disagrees with the experimental value $\left(7.6 \times 10^{-7} \mathrm{~s}^{-1}\right)$ by a factor of 152 . The origin of this discrepancy is explained as follows. Morris and Isaac determined the equilibrium constant for reaction 2 as a ratio of the experimental equilibrium constant $\left(K_{1}^{\text {Expt }}\right)$ of the formation of monochloramine $\left(10^{11.3}\right.$, Table 4$)$ and the experimental equilibrium constant, $K_{13}^{\text {Expt }}=10^{-2.6}$ of the disproportionation of $\mathrm{NH}_{2} \mathrm{Cl}$ to $\mathrm{NHCl}_{2}$ (reaction 13). These authors then used their estimate of the equilibrium constant of reaction 2 together with their experimental forward rate constant (Table 4) to deduce an experimental reverse rate constant for reaction 2. However, the value of $K_{13}^{\text {Expt }}$ of reaction 13 deviates from our theoretical equilibrium constant $\left(K_{13}^{\text {Comp }}=\right.$ $\left.10^{-0.5 \pm 1.1}\right)$. The discrepancy observed for the experimental equilibrium constant for the disproportionation reaction of monochloramine (reaction 13) propagates to the aqueous equilibrium constant for the chlorination reaction of monochloramine (reaction 2). Based on these considerations, we propose our value of the reverse rate constant, $k_{-2}^{\text {eq.10 }}=5 \times 10^{-9}$ $\mathrm{s}^{-1}$, as a better alternative to the previous estimate, $7.6 \times 10^{-7}$ $\mathrm{s}^{-1}$.

For the disproportionation reaction of two molecules of monochloramine to form dichloramine (reaction 13), we estimated a theoretical reverse rate constant, $k_{-13}^{\text {eq.10 }}$, of $0.2 \mathrm{M}^{-1}$ $\mathrm{s}^{-1}$, based on the rate constant for the forward reaction reported by Morris and Isaac, $\mathrm{k}_{13}^{\text {Expt }}=5.6 \times 10^{-2} \mathrm{M}^{-1} \mathrm{~s}^{-1}$, and the theoretical aqueous equilibrium constant of $K_{13}^{\text {Comp }}=$ $10^{-0.5 \pm 1.1}$. The resulting theoretically supported value of $k_{-13}^{\text {eq.10 }}$, $0.2 \mathrm{M}^{-1} \mathrm{~s}^{-1}$, is 2 orders of magnitude lower than the experimental estimate $\left(k_{-13}^{\text {Expt }}=24 \mathrm{M}^{-1} \mathrm{~s}^{-1}\right)$. We interpret that this discrepancy arises from the experimental aqueous equilibrium constant, $K_{13}^{\text {Expt }}=10^{-2.6,5}$ which is 2 orders of magnitude lower than the theoretical value, $K_{13}^{\text {Comp }}=10^{-0.5 \pm 1.1}$. Hence, using similar reasoning as for reaction 2 (above), we propose our theoretically supported value of $k_{-13}^{\text {eq. } 10}$ as an alternative to the experimentally derived estimate.

Further taking advantage of eq 10 , here we provide theoretical estimates of the reverse rate constants for the bromination reactions of ammonia and monochloramine (reactions 4 and 8), based on the previously determined $k_{f}^{\text {Expt }}$ values and our theoretical $K_{\mathrm{aq}}^{\text {Comp }}$ values (Table 3 ) for these reactions. For reaction 4 , we used the forward rate constant value proposed by Wajon and Morris, ${ }^{11} k_{4}^{\text {Expt }}=7.5 \pm 0.4 \times 10^{7}$ $\mathrm{M}^{-1} \mathrm{~s}^{-1}$. This value was confirmed later by Inman and Johnson $^{19}$ who reported a kinetic constant of $4 \times 10^{7} \mathrm{M}^{-1} \mathrm{~s}^{-1}$, and by Heeb ${ }^{101}$ who proposed a value of $5.5 \times 10^{7} \mathrm{M}^{-1} \mathrm{~s}^{-1}$. Our resulting estimate of $k_{-4}^{\text {eq. } 10}=4 \times 10^{-2} \mathrm{~s}^{-1}$ is reasonably consistent (within an expected uncertainty of an order of magnitude) with the value originally reported by Haag and Lietzke, $1.5 \times 10^{-3} \mathrm{~s}^{-1} .{ }^{67}$ For reaction 8 , which describes the production of chlorobromamine from the reaction of $\mathrm{NH}_{2} \mathrm{Cl}$ with $\mathrm{HOBr}$, we assumed the forward rate constant measured by Gazda and Margerum, $\mathrm{k}_{8}^{\mathrm{Expt}}=2.86 \pm 0.06 \times 10^{5} \mathrm{M}^{-1} \mathrm{~s}^{-1}$. ${ }^{51}$ This value implies a reverse rate constant of $k_{-8}^{\text {eq. } 10}=5 \times 10^{-5} \mathrm{~s}^{-1}$. Based on the theoretical aqueous equilibrium constants reported here, we were thus able to (re)assess the rate constants of some decomposition and disproportionation reactions involving chloramines, bromamines, and bromochloramines. Similar exercises could be applied to other available rate constant data involving halamines, based on the thermodynamic property data that we have provided in the present work.

$\mathrm{p} K_{a}$ Values for Chloramines, Bromamines, and Bromochloramines: Theoretical Estimates. Dissociation constants of chloramines and bromamines are difficult to 
Table 5. Estimated $\mathrm{p} K_{a}$ Values for the Cationic Conjugate Acid and Neutral Chloramines, Bromamines, Bromochloramines, and Methylated Halamines, According to Quantum Chemical LFER Results (SI Tables S5 and S6, Figure 1, and SI Figure S1)

\begin{tabular}{|c|c|c|c|}
\hline & $\mathrm{p} K_{a}$ & $\mathrm{p} K_{a}$ & $\mathrm{p} K_{a}$ \\
\hline deprotonation reactions & $X=\mathrm{Cl}$ & $X=\mathrm{Br}$ & $X=\mathrm{Cl}$ and $\mathrm{Br}$ \\
\hline $\mathrm{NH}_{3} \mathrm{X}^{+} \stackrel{K_{a}^{\mathrm{NH}_{3} \mathrm{X}^{+}}}{\rightleftharpoons} \mathrm{NH}_{2} \mathrm{X}+\mathrm{H}^{+}$ & $1.5 \pm 1^{a}, 1.44^{b}$ & $0.8 \pm 1^{a}$ & \\
\hline $\mathrm{NH}_{2} \mathrm{X}_{2}^{+} \stackrel{\mathrm{KH}_{a}^{\mathrm{NH}_{2} X_{2}^{+}}}{\rightleftharpoons} \mathrm{NHX}_{2}+\mathrm{H}^{+}$ & $-6.0 \pm 1^{a}$ & $-7.8 \pm 1^{a}$ & $-7.1 \pm 1^{a}$ \\
\hline $\mathrm{NH}_{2} \mathrm{XCH}_{3}+\stackrel{\mathrm{K}_{a}^{\mathrm{NH}_{2} \mathrm{XCH}_{3^{+}}} \rightleftharpoons}{\rightleftharpoons} \mathrm{NHXCH}_{3}+\mathrm{H}^{+}$ & $2.3 \pm 1^{a}, 1.55^{b}$ & $1.3 \pm 1^{a}$ & \\
\hline $\mathrm{NHX}\left(\mathrm{CH}_{3}\right)_{2}+\stackrel{\mathrm{K}_{a}^{\mathrm{NHX}\left(\mathrm{CH}_{3}\right)_{2}^{+}} \rightleftharpoons}{\rightleftharpoons} \mathrm{NX}\left(\mathrm{CH}_{3}\right)_{2}+\mathrm{H}^{+}$ & & $2.8 \pm 1^{a}, 2.88^{c}$ & \\
\hline $\mathrm{NHX}_{2} \mathrm{CH}_{3}+\stackrel{K_{a}^{\mathrm{NHX}_{2} \mathrm{CH}_{3}^{+}} \rightleftharpoons}{\rightleftharpoons} \mathrm{NX}_{2} \mathrm{CH}_{3}+\mathrm{H}^{+}$ & $-5.0 \pm 1^{a}$ & $-5.9 \pm 1^{a}$ & $-5.4 \pm 1^{a}$ \\
\hline $\mathrm{NH}_{2} \mathrm{X} \stackrel{K_{a}^{\mathrm{NH}_{2} X}}{\rightleftharpoons} \mathrm{NH} X^{-}+\mathrm{H}^{+}$ & $19.7 \pm 1^{d}$ & $24.7 \pm 1^{d}$ & \\
\hline $\mathrm{NHX} X_{2} \stackrel{K_{a}^{\mathrm{NHX} X_{2}}}{\rightleftharpoons} \mathrm{N} X_{2}^{-}+\mathrm{H}^{+}$ & $11.8 \pm 1^{d}$ & $19.6 \pm 1^{d}$ & $12.5 \pm 1^{d}$ \\
\hline
\end{tabular}

${ }^{a}$ The regression line used for this quantum chemical LFER is SI eq S13. ${ }^{b}$ Experimental values were taken from Margerum and Gray. ${ }^{4}$ Experimental

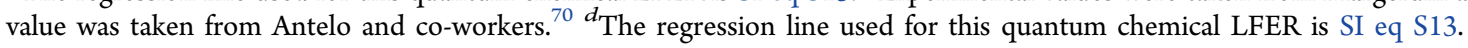

measure experimentally due to the high reactivities of these molecules in water. We estimated acid dissociation constant values for both the cationic conjugate acid and neutral amine functional group of chloramines, bromamines, bromochloramines, and selected methyl-substituted halamines.

We established a quantum chemical LFER (Table S5 in SI) based on previously reported experimental $\mathrm{p} K_{a}$ values of 16 substituted ammonium groups. We found a correlation coefficient of $R^{2}=0.98$ for the regression line of this computational LFER (Figure 1). The following equation was used to determine the computed $\mathrm{pK}_{a}$ values of several chlorammonium and bromammonium species (Table 5):

$$
\mathrm{p} K_{a}^{\text {Quantum Chemical LFER }}=1.83 \times \mathrm{p} K_{a}^{\text {uncorrected }}-6.25
$$

We also constructed a quantum chemical LFER (SI Table S6) based on theoretical and experimental $\mathrm{p} K_{a}$ data of four neutral amine functional groups. The regression line of the LFER (SI eq S13) established to estimate the $\mathrm{p} K_{a}$ values for neutral halamines had a correlation coefficient $R^{2}$ of 0.93 (SI Figure S1). This relationship was used to predict the $\mathrm{p} K_{a}$ values for neutral chloramines, bromamines, and bromochloramines (Table 5). Uncertainties of the predicted $\mathrm{p} K_{a}$ values were assigned as $\pm 1 \log$ unit, based on previous work on LFER prediction of $\mathrm{p} K_{a}$ values ${ }^{95,102,105,106}$ and on the observed scatter in the fitted LFER data (SI Tables S5 and S6).

Dissociation constants for chloramines, bromamines, bromochloramines, and methyl-substituted halamines reveal the $\mathrm{pH}$ dependent speciation of these reactive molecules in water. Computed $\mathrm{pK}_{a}$ data show that chloramines and bromamines are predominantly in neutral form at circumneutral $\mathrm{pH}$. However, selected cationic species and anionic species are still relevant for certain reactions. For example, $\mathrm{NH}_{3} \mathrm{Br}^{+}$was found to predominate over $\mathrm{NH}_{2} \mathrm{Br}$ in reactions with substituted phenols studied by Heeb et al. at neutral $\mathrm{pH}$, despite the low $\mathrm{p} K_{a}$ of monobromammonium $(\sim 0.8)$, due to the much higher electrophilicity of monobromammonium relative to monobromamine. ${ }^{101}$ On the other hand, the computed $\mathrm{p} K_{a}$ values of $\mathrm{NHCl}_{2}$ and $\mathrm{NHClBr}(\sim 11.8$ and $\sim 12.5$, respectively $)$ are down-shifted relative to the less acidic monohalogenated species $\mathrm{NH}_{2} \mathrm{Cl}$ and $\mathrm{NH}_{2} \mathrm{Br}$, due to the stabilization of the anion by the presence of an additional electron-withdrawing substituent. The resulting deprotonated anionic species may be relevant for reactions with electrophiles. For example, recent theoretical work indicated that ozone oxidizes primarily the deprotonated anionic form of bromo- $N, N$-dimethylsulfamide rather than the neutral species $\left(\mathrm{p} K_{a} \sim 9.0\right)$, due to the higher nucleophilicity of the anionic form.

\section{ASSOCIATED CONTENT}

\section{S Supporting Information}

The Supporting Information is available free of charge on the ACS Publications website at DOI: 10.1021/acs.est.6b03219.

Computational modeling of free energies of solvation and aqueous free energies of reaction; experimental Henry's law constants and conversion factor; assignment of the error bounds for the computed aqueous standard free energies of formation; aqueous free energy of the proton; evaluation of B2PLYPD method for total atomization energies for selected halogen species; evaluation of implicit solvent models for the prediction of free energies of solvation for halamines and related species; evaluation of the gas phase equilibrium constants and the aqueous equilibrium constant values using the SMD and COSMO implicit solvent models and the cluster-continuum-SMD approach; and experimental and quantum chemical computed $\mathrm{pK}_{a}$ values for neutral chloramines and bromamines and for the cationic conjugate acid ammonium functional groups of several halamines (PDF)

\section{AUTHOR INFORMATION}

\section{Corresponding Author}

*Phone: +41 (0)58 765 5482; fax: +41 (0)58 765 5802; e-mail: samuel.arey@eawag.ch.

\section{ORCID}

J. Samuel Arey: 0000-0002-3189-1585

\section{Present Address}

${ }^{\S}$ BU E13, Eawag, Überlandstrasse 133, 8600 Dübendorf, Switzerland.

\section{Notes}

The authors declare no competing financial interest. 


\section{ACKNOWLEDGMENTS}

We thank Urs von Gunten (Eawag and EPFL) and Michele B. Heeb (EPFL) for comments on the manuscript and for helpful discussions, as well as Giovanni Cangiani (EPFL) and Jennifer Guerard (UA Fairbanks). We also thank the EPFL centralized HPC facilities for computational resources and support.

\section{REFERENCES}

(1) Korshin, G. V. In Aquatic Redox Chemistry, Chapter 11; Tratnyek, P., Grundl, T., Haderlein, S., Eds.; American Chemical Society: Washington, DC, 2012; pp 223-245.

(2) Weil, I.; Morris, J. C. Kinetic Studies on the Chloramines. I. The Rates of Formation of Monochloramines, N-Chlormethylamine and N-Chlordimethylamine. J. Am. Chem. Soc. 1949, 71, 1664-1671.

(3) Morris, J. C. In Princ. Appl. Water Chem.; Faust, S. D., Hunter, J., Eds.; 1967; pp 23-53.

(4) Margerum, D. W.; Gray, E. T. Organometals Organometalloids: Occurrence and Fate in the Environment, Chapter 17; American Chemical Society: Washinggton, DC, 1978; pp 278-291.

(5) Morris, J. C.; Isaac, R. A. In Water Chlorination Environ. Impact Health Effects; Jolley, R. L., Brungs, W. A., Cotruvo, J. A., Cumming, R. B., Mattice, J. S., Jacobs, V. A., Eds.; Ann Arbor Science: Ann Arbor, MI, 1981; Vol. 4; Chapter 2, pp 50-62.

(6) Hand, V. C.; Margerum, D. W. Kinetics and Mechanisms of Decomposition of Dichloramine in Aqueous Solution. Inorg. Chem. 1983, 22, 1449-1456.

(7) Jafvert, C. T.; Valentine, R. L. Reaction Scheme for the Chlorination of Ammoniacal Water. Environ. Sci. Technol. 1992, 26, 577-586.

(8) Lei, H.; Mariñas, B. J.; Minear, R. A. Bromamine decomposition kinetics in aqueous solutions. Environ. Sci. Technol. 2004, 38, 2111-9.

(9) Vikesland, P. J.; Ozekin, K.; Valentine, R. L. Monochloramine decay in model and distribution system waters. Water Res. 2001, 35, $1766-76$.

(10) Galal-Gorchev, H.; Morris, J. C. Formation and Stability of Bromamide, Bromimide, and Nitrogen Tribromide in Aqueous Solution. Inorg. Chem. 1965, 4, 899-905.

(11) Wajon, J. E.; Morris, J. C. Rates of Formation of N-Bromo Amines in Aqueous Solution. Inorg. Chem. 1982, 21, 4258-4263.

(12) Soulard, B. M.; Bloc, F.; Hatterer, A. Diagrams of Existence of Chloramines and Bromamines in Aqueous Solution. J. Chem. Soc., Dalton Trans. 1981, 2300-2310.

(13) Valentine, R. L.; Jafvert, C. T.; Leung, S. W. Evaluation of Chloramine Decomposition Model Incorporating General-Acid Catalysis. Water Res. 1988, 22, 1147-1153.

(14) Cromer, J. L.; Inman, G. W.; Johnson, J. D. In Chem. Wastewater Technol.; Rubin, A. J., Ed.; Ann Arbor Science: Ann Arbor, MI, 1980; Chapter 14, pp 213-225.

(15) Inman, G. W.; LaPointe, T. F.; Jonhson, J. D. Kinetics of Nitrogen Tribromide Decomposition in Aqueous Solution. Inorg. Chem. 1976, 15, 3037-3042.

(16) Saguinsin, J. L. S.; Morris, J. C. In Disinfect. - Water wastewater Treat.; Johnson, J., Ed.; Ann Arbor Science, Ann Arbor, MI, 1975; pp 277-299.

(17) Gray, E. T.; Margerum, D. W.; Huffman, R. P. In Organometals Organometalloids Occur. Fate Environ.; Brenchman, F., Bellama, J., Eds.; 1978; Chapter 16, pp 264-277.

(18) Valentine, R. L.; Jafvert, C. T. General Acid Catalysis of Monochloramine Disproportionation. Environ. Sci. Technol. 1988, 22, 691-696.

(19) Inman, G. W.; Johnson, J. D. Kinetics of Monobromamine Disproportionation-Dibromamine formation in aqueous ammonia solutions. Environ. Sci. Technol. 1984, 18, 219-224.

(20) Luh, J.; Mariñas, B. J. Kinetics of bromochloramine formation and decomposition. Environ. Sci. Technol. 2014, 48, 2843-52.

(21) Allard, S.; Tan, J.; Joll, C. A.; von Gunten, U. Mechanistic Study on the Formation of $\mathrm{Cl}$-/Br-/I-Trihalomethanes during Chlorination/
Chloramination Combined with a Theoretical Cytotoxicity Evaluation. Environ. Sci. Technol. 2015, 49, 11105-14.

(22) Isaac, R. A.; Morris, J. C. Transfer of Active Chlorine from Chloramine to Nitrogenous Organic Compounds: 1. Kinetics. Environ. Sci. Technol. 1983, 17, 738-742.

(23) Diehl, A. C.; Speitel, G. E., Jr.; Symons, J. M.; Krasner, S. W.; Hwang, C. J.; Barrett, S. E. DBP formation during chloramination. J. Am. Water Works Assoc. 2000, 92, 76-90.

(24) National Research Council, Drinking Water and Health, Vol. 2; The National Academies Press, Washington, DC, 1980.

(25) National Research Council, Drinking Water and Health, Vol. 7 Disinfectants and Disinfectants By-Products; The National Academies Press, Washington, DC, 1987.

(26) Hua, G.; Reckhow, D. A. Comparison of disinfection byproduct formation from chlorine and alternative disinfectants. Water Res. 2007, $41,1667-78$.

(27) Kim, H.; Shim, J.; Lee, S. Formation of disinfection by-products in chlorinated swimming pool water. Chemosphere 2002, 46, 123-130.

(28) Le Roux, J.; Gallard, H.; Croué, J.-P. Chloramination of nitrogenous contaminants (pharmaceuticals and pesticides): NDMA and halogenated DBPs formation. Water Res. 2011, 45, 3164-74.

(29) Malliarou, E.; Collins, C.; Graham, N.; Nieuwenhuijsen, M. J. Haloacetic acids in drinking water in the United Kingdom. Water Res. 2005, 39, 2722-30.

(30) Bi, X.; Xu, B.; Lin, Y.-L.; Hu, C.-Y.; Ye, T.; Qin, C. Monochloramination of Oxytetracycline: Kinetics, Mechanisms, Pathways, and Disinfection By-Products Formation. Clean: Soil, Air, Water 2013, 41, 969-975.

(31) Duirk, S. E.; Valentine, R. L. Modeling dichloroacetic acid formation from the reaction of monochloramine with natural organic matter. Water Res. 2006, 40, 2667-74.

(32) Shah, A. D.; Mitch, W. A. Halonitroalkanes, Halonitriles, Haloamides, and N-Nitrosamines: A Critical Review of Nitrogenous Disinfection Byproduct Formation Pathways. Environ. Sci. Technol. 2012, 46, 119-131.

(33) Sakai, H.; Tokuhara, S.; Murakami, M.; Kosaka, K.; Oguma, K.; Takizawa, S. Comparison of chlorination and chloramination in carbonaceous and nitrogenous disinfection byproduct formation potentials with prolonged contact time. Water Res. 2016, 88, 661-70.

(34) Soltermann, F.; Canonica, S.; von Gunten, U. Trichloramine reactions with nitrogenous and carbonaceous compounds: Kinetics, products and chloroform formation. Water Res. 2015, 71, 318-329.

(35) Le Roux, J.; Nihemaiti, M.; Croué, J.-P. The role of aromatic precursors in the formation of haloacetamides by chloramination of dissolved organic matter. Water Res. 2016, 88, 371-9.

(36) Chu, C.; Erickson, P. R; Lundeen, R. A.; Stamatelatos, D.; Alaimo, P. J.; Latch, D. E.; McNeill, K. Photochemical and Nonphotochemical Transformations of Cysteine with Dissolved Organic Matter. Environ. Sci. Technol. 2016, 50, 6363-6373.

(37) Chuang, Y.-H.; Tung, H.-H. Formation of trichloronitromethane and dichloroacetonitrile in natural waters: precursor characterization, kinetics and interpretation. J. Hazard. Mater. 2015, $283,218-26$.

(38) Schreiber, I. M.; Mitch, W. A. Influence of the Order of Reagent Addition on NDMA Formation during Chloramination. Environ. Sci. Technol. 2005, 39, 3811-8.

(39) Schreiber, I. M.; Mitch, W. A. Nitrosamine Formation Pathway Revisited: the Importance of Chloramine Speciation and Dissolved Oxygen. Environ. Sci. Technol. 2006, 40, 6007-14.

(40) Selbes, M.; Kim, D.; Ates, N.; Karanfil, T. The roles of tertiary amine structure, background organic matter and chloramine species on NDMA formation. Water Res. 2013, 47, 945-53.

(41) Kristiana, I.; Tan, J.; Joll, C. A.; Heitz, A.; von Gunten, U.; Charrois, J. W. A. Formation of $\mathrm{N}$-nitrosamines from chlorination and chloramination of molecular weight fractions of natural organic matter. Water Res. 2013, 47, 535-546.

(42) Choi, J.; Valentine, R. L. Formation of N-nitrosodimethylamine (NDMA) from reaction of monochloramine: a new disinfection byproduct. Water Res. 2002, 36, 817-24. 
(43) Le Roux, J.; Croue, J.-P.; Deborde, M. NDMA Formation by Chloramination of Ranitidine: Kinetics and Mechanism. Environ. Sci. Technol. 2012, 46, 11095-11103.

(44) Luh, J.; Mariñas, B. J. Bromide ion effect on N-nitrosodimethylamine formation by monochloramine. Environ. Sci. Technol. 2012, 46, 5085-92.

(45) Chen, Z.; Valentine, R. L. Modeling the formation of Nnitrosodimethylamine (NDMA) from the reaction of natural organic matter (NOM) with monochloramine. Environ. Sci. Technol. 2006, 40, 7290-7.

(46) Vikesland, P. J.; Valentine, R. L. Effect of Natural Organic Matter on Monochloramine Decomposition: Pathway Elucidation through the Use of Mass and Redox Balances. Environ. Sci. Technol. 1998, 32, 1409-1416.

(47) Liu, Y. D.; Selbes, M.; Zeng, C.; Zhong, R.; Karanfil, T. Formation Mechanism of NDMA from Ranitidine, Trimethylamine, and Other Tertiary Amines during Chloramination: A Computational Study. Environ. Sci. Technol. 2014, 48, 8653-63.

(48) Trofe, T. W.; Inman, G. W.; Johnson, J. D. Kinetics of monochloramine decomposition in the presence of bromide. Environ. Sci. Technol. 1980, 14, 544-549.

(49) Wajon, J. E., Morris, J. C. In Water Chlorination Environ. Impact Health Effects, Chapter 16; Jolley, R. L., Brungs, W. A., Cumming, R. B., Jacobs, V. A., Eds.; Ann Arbor Science, Ann Arbor, MI, 1980; Vol. 3, pp 171-181.

(50) Jonhson, J. D.; Overby, R. Bromine and Bromamine Disinfection Chemistry. J. Sanit. Eng. Div. 1971, 97, 617-628.

(51) Gazda, M.; Margerum, D. W. Reactions of Monochloramine with $\mathrm{Br} 2, \mathrm{Br} 3-, \mathrm{HOBr}$, and $\mathrm{OBr}-$ : Formation of Bromochloramines. Inorg. Chem. 1994, 33, 118-123.

(52) Bousher, A.; Brimblecombe, P.; Midgley, D. Kinetics of reactions in solutions containing monochloramine and bromide. Water Res. 1989, 23, 1049-1058.

(53) LaPointe, T. F.; Inman, G. W.; Johnson, J. D. Disinfect. Water wastewater Treat; 1975; Chapter 15, pp 301-338.

(54) Bousher, A.; Brimblecombe, P.; Midgley, D. Rate of hypobromite formation in chlorinated seawater. Water Res. 1986, 20, $865-870$.

(55) Kumar, K.; Margerum, D. W. Kinetics and Mechanism of General-Acid-Assisted Oxidation of Bromide by Hypochlorite and Hypochlorous Acid. Inorg. Chem. 1987, 26, 2706-2711.

(56) Gazda, M.; Dejarme, L. E.; Choudhury, T. K.; Cooks, R. G.; Margerum, D. W. Mass Spectrometric Evidence for the Formation of Bromochloramine and N-Bromo-N-chloromethylamine in Aqueous Solution. Environ. Sci. Technol. 1993, 27, 557-561.

(57) Valentine, R. L. Bromochloramine oxidation of N,N-diethyl-pphenylenediamine in the presence of monochloramine. Environ. Sci. Technol. 1986, 20, 166-70.

(58) Lei, H.; Minear, R. A.; Mariñas, B. J. Cyanogen bromide formation from the reactions of monobromamine and dibromamine with cyanide ion. Environ. Sci. Technol. 2006, 40, 2559-64.

(59) Le Roux, J.; Gallard, H.; Croué, J.-P. Formation of NDMA and Halogenated DBPs by Chloramination of Tertiary Amines: the Influence of Bromide Ion. Environ. Sci. Technol. 2012, 46, 1581-9.

(60) Chen, Z.; Yang, L.; Zhai, X.; Zhao, S.; Li, A.; Shen, J. Nnitrosamine formation during chlorination/chloramination of bromide-containing water. Water Sci. Technol.: Water Supply 2010, 10, $462-471$.

(61) Heller-Grossman, L.; Idin, A.; Limoni-Relis, B.; Rebhun, M. Formation of Cyanogen Bromide and Other Volatile DBPs in the Disinfection of Bromide-Rich Lake Water. Environ. Sci. Technol. 1999, 33, 932-937.

(62) Pattison, D. I.; Davies, M. J. Kinetic Analysis of the Reactions of Hypobromous Acid with Protein Components: Implications for Cellular Damage and Use of 3-Bromotyrosine as a Marker of Oxidative Stress. Biochemistry 2004, 43, 4799-4809.

(63) Pattison, D. I.; O’Reilly, R. J.; Ska, O.; Radom, L.; Anderson, R. F.; Davies, M. J. One-Electron Reduction of $\mathrm{N}$-Chlorinated and $\mathrm{N}$
-Brominated Species Is a Source of Radicals and Bromine Atom Formation. Chem. Res. Toxicol. 2011, 24, 371-382.

(64) Rees, M. D.; McNiven, T. N.; Davies, M. J. Degradation of extracellular matrix and its components by hypobromous acid. Biochem. J. 2007, 401, 587-96.

(65) Hawkins, C. L.; Davies, M. J. The role of reactive N-bromo species and radical intermediates in hypobromous acid-induced protein oxidation. Free Radical Biol. Med. 2005, 39, 900-912.

(66) Kumar, K.; Shinness, R. W.; Margerum, D. W. Kinetics and Mechanisms of the Base Decomposition of Nitrogen Trichloride in Aqueous Solution. Inorg. Chem. 1987, 26, 3430-3434.

(67) Haag, W. R.; Lietzke, M. H. Water Chlorination. Environmental Impact and Health Effects.; Ann Arbor Science Publishers: Ann Arbor, MI, 1980; Vol. 3, pp 415-426.

(68) Hofmann, R.; Andrews, R. C. Ammoniacal bromamines: a review of their influence on bromate formation during ozonation. Water Res. 2001, 35, 599-604.

(69) Sugam, R.; Helz, G. R. Chlorine Speciation in seawater; a metastable equilibrium model for $\mathrm{Cl}$ and $\mathrm{Br}$ species. Chemosphere 1981, 10, 41-57.

(70) Antelo, J. M.; Arce, F.; Crugeiras, J.; Gray, E. T.; Yebra, P. Kinetics and thermodynamics of the reaction of aliphatic $\mathrm{N}$ bromamines with bromide ion in acid media, and the $\mathrm{pKa}$ of $\mathrm{N}$ bromamines. J. Chem. Soc., Perkin Trans. 2 1999, 651-656.

(71) Andrés, J.; Canle L, M.; García, M.; Rodríguez Vázquez, L.; Santaballa, J. A B3LYP/6-31G** study on the chlorination of ammonia by hypochlorous acid. Chem. Phys. Lett. 2001, 342, 405-410.

(72) Rayson, M. S.; Altarawneh, M.; Mackie, J. C.; Kennedy, E. M.; Dlugogorski, B. Z. Theoretical Study of the Ammonia-Hypochlorous Acid Reaction Mechanism. J. Phys. Chem. A 2010, 114, 2597-606.

(73) Tarade, T.; Vrček, V. Reactivity of amines with hypochlorous acid: Computational study of steric, electronic, and medium effects. Int. J. Quantum Chem. 2013, 113, 881-890.

(74) Rayne, S.; Forest, K. Thermodynamic properties of chloramine formation and related reactions during water treatment: A G4MP2, G4, and W1BD theoretical study. J. Environ. Sci. Health, Part A: Toxic/ Hazard. Subst. Environ. Eng. 2014, 49, 753-62.

(75) Baboul, A. G.; Curtiss, L. A.; Redfern, P. C.; Raghavachari, K. Gaussian-3 theory using density functional geometries and zero-point energies. J. Chem. Phys. 1999, 110, 7650.

(76) Trogolo, D.; Arey, J. S. Benchmark Thermochemistry of Chloramines, Bromamines, and Bromochloramines: Halogen Oxidants Stabilized by Electron Correlation. Phys. Chem. Chem. Phys. 2015, 17, 3584-3598.

(77) Trogolo, D.; Arey, J. S. Correction to "Benchmark Thermochemistry of Chloramines, Bromamines, and Bromochloramines: Halogen Oxidants Stabilized by Electron Correlation. Phys. Chem. Chem. Phys. 2016, 18, 31337.

(78) Ben-Naim, A. Solvation Thermodynamics; Plenum Press: New York, 1987; p 246.

(79) Bryantsev, V. S.; Diallo, M. S.; Goddard, W. A., III Calculation of Solvation Free Energies of Charged Solutes Using Mixed Cluster/ Continuum Models. J. Phys. Chem. B 2008, 112, 9709-19.

(80) Grimme, S. Semiempirical hybrid density functional with perturbative second-order correlation. J. Chem. Phys. 2006, 124, 034108 .

(81) Schwabe, T.; Grimme, S. Double-hybrid density functionals with long-range dispersion corrections: higher accuracy and extended applicability. Phys. Chem. Chem. Phys. 2007, 9, 3397-3406.

(82) Dunning, T. H., Jr. Gaussian basis sets for use in correlated molecular calculations. I. The atoms boron through neon and hydrogen. J. Chem. Phys. 1989, 90, 1007-1023.

(83) Kendall, R. A.; Dunning, T. H., Jr.; Harrison, R. J. Electron affinities of the first-row atoms revisited. Systematic basis sets and wave functions. J. Chem. Phys. 1992, 96, 6796-6806.

(84) Woon, D. E.; Dunning, T. H. Gaussian basis sets for use in correlated molecular calculations. III. The atoms aluminum through argon. J. Chem. Phys. 1993, 98, 1358.

(85) Frisch, M. J. et al. Gaussian 09 Revision D.01 2009. 
(86) Marenich, A. V.; Cramer, C. J.; Truhlar, D. G. Universal Solvation Model Based on Solute Electron Density and on a Continuum Model of the Solvent Defined by the Bulk Dielectric Constant and Atomic Surface Tensions. J. Phys. Chem. B 2009, 113, 6378-96.

(87) Barone, V.; Cossi, M. Quantum Calculation of Molecular Energies and Energy Gradients in Solution by a Conductor Solvent Model. J. Phys. Chem. A 1998, 102, 1995-2001.

(88) Cossi, M.; Rega, N.; Scalmani, G.; Barone, V. Energies, structures, and electronic properties of molecules in solution with the C-PCM solvation model. J. Comput. Chem. 2003, 24, 669-81.

(89) Miertuš, S.; Scrocco, E.; Tomasi, J. Electrostatic interaction of a solute with a continuum. A direct utilization of ab initio molecular potentials for the prevision of solvent effects. Chem. Phys. 1981, 55, $117-129$.

(90) Tomasi, J.; Mennucci, B.; Cammi, R. Quantum mechanical continuum solvation models. Chem. Rev. 2005, 105, 2999-3093.

(91) Scalmani, G.; Frisch, M. J. Continuous surface charge polarizable continuum models of solvation. I. General formalism. J. Chem. Phys. 2010, 132, 114110.

(92) Klamt, A.; Schüürmann, G. COSMO: a new approach to dielectric screening in solvents with explicit expressions for the screening energy and its gradient. J. Chem. Soc., Perkin Trans. 2 1993, 799.

(93) York, D. M.; Karplus, M. A Smooth Solvation Potential Based on the Conductor-Like Screening Model. J. Phys. Chem. A 1999, 103, 11060-11079.

(94) Valiev, M.; Bylaska, E. J.; Govind, N.; Kowalski, K.; Straatsma, T. P.; Van Dam, H.; Wang, D.; Nieplocha, J.; Apra, E.; Windus, T. L.; de Jong, W. A. NWChem: A comprehensive and scalable open-source solution for large scale molecular simulations. Comput. Phys. Commun. 2010, 181, 1477-1489.

(95) Trogolo, D.; Mishra, B. K.; Heeb, M. B.; von Gunten, U.; Arey, J. S. Molecular Mechanism of NDMA Formation from N,NDimethylsulfamide During Ozonation: Quantum Chemical Insights into a Bromide-Catalyzed Pathway. Environ. Sci. Technol. 2015, 49, 4163-75.

(96) Goerigk, L.; Grimme, S. A General Database for Main Group Thermochemistry, Kinetics, and Noncovalent Interactions - Assessment of Common and Reparameterized (meta-) GGA Density Functionals. J. Chem. Theory Comput. 2010, 6, 107-126.

(97) Korth, M.; Grimme, S. "Mindless" DFT Benchmarking. J. Chem. Theory Comput. 2009, 5, 993-1003.

(98) Karton, A.; Parthiban, S.; Martin, J. M. Post-CCSD(T) ab initio thermochemistry of halogen oxides and related hydrides XOX, XOOX, HOX, XOn, and HXOn $(\mathrm{X}=\mathrm{F}, \mathrm{Cl})$, and evaluation of DFT methods for these systems. J. Phys. Chem. A 2009, 113, 4802-16.

(99) Improta, R.; Barone, V.; Scalmani, G.; Frisch, M. J. A statespecific polarizable continuum model time dependent density functional theory method for excited state calculations in solution. J. Chem. Phys. 2006, 125, 054103.

(100) Improta, R.; Scalmani, G.; Frisch, M. J.; Barone, V. Toward effective and reliable fluorescence energies in solution by a new state specific polarizable continuum model time dependent density functional theory approach. J. Chem. Phys. 2007, 127, 074504.

(101) Heeb, M. B.; Kristiana, I.; Trogolo, D.; Arey, J. S.; von Gunten, U. Formation and reactivity of inorganic and organic chloramines and bromamines during oxidative water treatment. Water Res. 2016, in press. DOI: $10.1016 /$ j.watres.2016.11.065

(102) Ho, J.; Coote, M. L. A universal approach for continuum solvent pKa calculations: are we there yet? Theor. Chem. Acc. 2010, $125,3-21$.

(103) Ho, J. Are thermodynamic cycles necessary for continuum solvent calculation of pKas and reduction potentials? Phys. Chem. Chem. Phys. 2015, 17, 2859-68.

(104) Ho, J.; Ertem, M. Z. Calculating Free Energy Changes in Continuum Solvation Models. J. Phys. Chem. B 2016, 120, 1319-29.
(105) Zhang, S. A Reliable and Efficient First Principles-Based Method for Predicting pKa Values. 4. Organic Bases. J. Comput. Chem. 2012, 33, 2469-82.

(106) Tentscher, P. R.; Eustis, S. N.; McNeill, K.; Arey, J. S. Aqueous Oxidation of Sulfonamide Antibiotics: Aromatic Nucleophilic Substitution of an Aniline Radical Cation. Chem. - Eur. J. 2013, 19, 11216-23.

(107) Casasnovas, R.; Ortega-Castro, J.; Frau, J.; Donoso, J.; Muñoz, F. Theoretical pKa calculations with continuum model solvents, alternative protocols to thermodynamic cycles. Int. J. Quantum Chem. 2014, 114, 1350-1363.

(108) Montgomery, J. A.; Frisch, M. J.; Ochterski, J. W.; Petersson, G. A. A complete basis set model chemistry. VI. Use of density functional geometries and frequencies. J. Chem. Phys. 1999, 110, 2822-27.

(109) Montgomery, J. A., Jr.; Frisch, M. J.; Ochterski, J. W.; Petersson, G. A. A complete basis set model chemistry. VII. Use of the minimum population localization method. J. Chem. Phys. 2000, 112, $6532-6542$

(110) Liptak, M. D.; Shields, G. C. Accurate pKa Calculations for Carboxylic Acids Using Complete Basis Set and Gaussian-n Models Combined with CPCM Continuum Solvation Methods. J. Am. Chem. Soc. 2001, 123, 7314-9.

(111) Liptak, M. D.; Shields, G. C. Thermodynamic Cycles Used for pKa Complete Basis Set and Gaussian- n Models Combined with CPCM Continuum Solvation Methods. Int. J. Quantum Chem. 2001, $85,727-741$.

(112) Liptak, M. D.; Gross, K. C.; Seybold, P. G.; Feldgus, S.; Shields, G. C. Absolute pKa Determinations for Substituted Phenols. J. Am. Chem. Soc. 2002, 124, 6421-6427.

(113) Casasnovas, R.; Frau, J.; Ortega-Castro, J.; Salva, A.; Donoso, J.; Muñoz, F. Absolute and relative pKa calculations of mono and diprotic pyridines by quantum methods. J. Mol. Struct.: THEOCHEM 2009, 912, 5-12.

(114) Zhao, Y.; Schultz, N. E.; Truhlar, D. G. Exchange-correlation functional with broad accuracy for metallic and nonmetallic compounds, kinetics, and noncovalent interactions. J. Chem. Phys. 2005, 123, 161103.

(115) Everett, D. H.; Pinsent, B. R. W. The Dissociation Constants of Ethylene Diammonium and Hexamethylene Diammonium Ions from 0 degrees to 60 degrees C. Proc. R. Soc. London, Ser. A 1952, 215, 416429.

(116) Hall, N. F.; Sprinkle, M. R. Relations between the structure and strength of certain organic bases in aqueous solution. J. Am. Chem. Soc. 1932, 54, 3469-3485.

(117) Hansson, J. Reaction between alkene oxides and amines. VII. Determination of dissociation constants for some mixed tertiary aliphatic amines. Sven. Kem. Tidskr. 1955, 67, 256-262.

(118) Brown, H. C.; McDaniel, D. H.; Hafliger, O.; Nachod, F. C. In Determ. Org. Struct. by Phys. Methods; Braude, E., Nachod, F., Eds.; Academic Press: New York, 1955; p 810.

(119) Bissot, T. C.; Parry, R. W.; Campbell, D. H. The Physical and Chemical Properties of the Methylhydroxylamines 1. J. Am. Chem. Soc. 1957, 79, 796-800.

(120) Schwarzenbach, G. Zur Berechnung intramolekularer Atomabstände aus den Dissoziationskonstanten zweibasischer Säuren II. Die Acidität einiger Dicarbonsäuren und Polymethylen-diammoniumionen in Wasser-Alkohol-Mischungen. Helv. Chim. Acta 1933, 16, 522-528.

(121) Hodgman, C. D., Ed. Handbook of Chemistry and Physics; Chemical Rubber Publishing Company: Cleveland, OH, 1951; pp 1636-7.

(122) Bordwell, G. Equilibrium Acidities in Dimethyl Sulfoxide Solution. Acc. Chem. Res. 1988, 21, 456-463.

(123) Hannigan, T. J.; Spillane, W. J. Basicity of NitrogenSulphur(VI) Compounds. Part 4.1 Ionization of Di- and Trisubstituted Sulphamides. J. Chem. Soc., Perkin Trans. 2 1982, 851-855.

(124) Sander, R. In NIST Chem. WebBook, NIST Stand. Ref. Database Number 69; Linstrom, P. J., Mallard, W. G., Eds.; National Institute of Standards and Technology: Gaithersburg MD, 20899, 2011. 
(125) Marenich, A. V.; Kelly, C. P.; Thompson, J. D.; Hawkins, G. D.; Chambers, C. C.; Giesen, D. J.; Winget, P.; Cramer, C. J.; Truhlar, D. G. Minnesota Solvation Database. 2012.

(126) Sander, R. Compilation of Henry's law constants (version 4.0) for water as solvent. Atmos. Chem. Phys. 2015, 15, 4399-4981.

(127) Stumm, W.; Morgan, J. J. Aquatic Chemistry: Chemical Equilibria and Rates in Natural Waters, 3rd ed.; Wiley-Interscience, 1995; p 1040.

(128) Granstrom, M. L. The Disproportionation of Monochloramine. Ph.D. thesis, Harvard University, 1954.

(129) Anslyn, E. V.; Dougherty, D. A. Modern Physical Organic Chemistry; University Science Books, 2006; p 1095. 